\title{
Acute hypoxia induces apoptosis of pancreatic $\beta$-cell by activation of the unfolded protein response and upregulation of CHOP
}

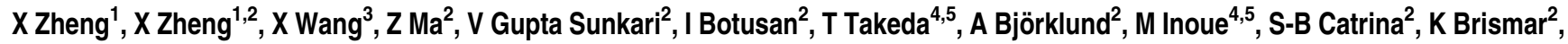 \\ L Poellinger ${ }^{1,6}$ and TS Pereira ${ }^{*, 1}$
}

The success of pancreatic $\beta$-cells transplantation to treat type 1 diabetes has been hindered by massive $\beta$-cell dysfunction and loss of $\beta$-cells that follows the procedure. Hypoxia-mediated cell death has been considered one of the main difficulties that must be overcome for transplantation to be regarded as a reliable therapy. Here we have investigated the mechanisms underlying $\beta$-cell death in response to hypoxia $\left(1 \% \mathrm{O}_{2}\right)$. Our studies show that mouse insulinoma cell line 6 (Min6) cells undergo apoptosis with caspase- 3 activation occurring as early as $2 \mathrm{~h}$ following exposure to hypoxia. Hypoxia induces endoplasmic reticulum stress in Min6 cells leading to activation of the three branches of the unfolded protein response pathway. In response to hypoxia the pro-apoptotic transcription factor C/EBP homologous protein (CHOP) is upregulated. The important role of CHOP in the apoptotic process was highlighted by the rescue of Min6 cells from hypoxia-mediated apoptosis observed in CHOP-knockdown cells. Culturing isolated pancreatic mouse islets at normoxia showed intracellular hypoxia with accumulation of hypoxiainducible factor- $1 \alpha$ and upregulation of CHOP, the latter one occurring as early as $4 \mathrm{~h}$ after isolation. Finally, we observed that pancreatic islets of type $2 \mathrm{db} / \mathrm{db}$ diabetic mice were more hypoxic than their counterpart in normoglycemic animals. This finding indicates that hypoxia-mediated apoptosis may occur in type 2 diabetes.

Cell Death and Disease (2012) 3, e322; doi:10.1038/cddis.2012.66; published online 14 June 2012

Subject Category: Experimental Medicine

Transplantation of the whole pancreas or allogenic islet transplantation is the therapy of choice to cure type 1 diabetes patients and to minimize recurrent severe hypoglycemia achieved by exogenous insulin treatment. Whole pancreas transplantation has considerable peri-transplant complications and post-transplantation morbidity. In contrast, islet transplantation is minimally invasive and has low morbidity. However, islet transplantation is neither currently leading to insulin independence nor becoming the successful therapy that was initially predicted, and it is considered that significant progress must be achieved for this procedure to be regarded as a reliable therapy. ${ }^{1}$ One of the main problems of islet transplantation is the massive cell death occurring after islet isolation and transplantation, with the consequent requirement of high number of islets in order to restore glucose homeostasis. $^{2}$
Pancreatic $\beta$-cells consume large amounts of oxygen during insulin secretion due to the high demand of mitochondrial respiration. Oxygen dependence of $\beta$-cell function renders these cells very sensitive to hypoxia. Studies have shown that 1 day after intraportal transplantation about $70 \%$ of the islets are hypoxic. ${ }^{3}$ The hypoxic state of $\beta$-cells following isolation and transplantation of pancreatic islets has been suggested to be a major contributor to $\beta$-cell dysfunction and apoptosis. $^{3,4}$

Adaptive responses to hypoxia $\left(1 \% \mathrm{O}_{2}\right)$ are regulated by hypoxia-inducible factors (HIFs) that induce transcription of genes involved, for example, in angiogenesis, glucose metabolism, and erythropoiesis, In contrast to hypoxia of $1 \% \mathrm{O}_{2}$, in cancer cells and mouse embryonic fibroblasts (MEFs) exposure to $<0.1 \% \mathrm{O}_{2}$ (severe hypoxia or anoxia) induces endoplasmic reticulum (ER) stress and activation of

\footnotetext{
${ }^{1}$ Department of Cell and Molecular Biology, Karolinska Institutet, Stockholm, Sweden; ${ }^{2}$ Department of Molecular Medicine and Surgery, Rolf Luft Center for Diabetes and Endocrinology, Karolinska Institutet, Stockholm, Sweden; ${ }^{3}$ Department of Oncology-Pathology, Cancer Center Karolinska, Karolinska Institutet, Stockholm, Sweden; ${ }^{4}$ Department of Biochemistry, Osaka Medical Center for Cancer and Cardiovascular Diseases, Osaka, Japan; ${ }^{5}$ Department of Clinical and Experimental Pathophysiology, Osaka University, Graduate School of Pharmaceutical Sciences, Osaka, Japan and ${ }^{6}$ Cancer Science Institute of Singapore, National University of Singapore, Singapore, Singapore

${ }^{*}$ Corresponding author: TS Pereira, Department of Cell and Molecular Biology, Karolinska Institutet, Von Eulers väg 3, SE-17177 Stockholm, Sweden. Tel: +46 85248 7331; Fax: +46 8 348819; E-mail: teresa.pereira@ki.se

Keywords: hypoxia; pancreatic $\beta$-cells; UPR; ER stress; apoptosis; CHOP

Abbreviations: ATF4, activating transcription factor 4; ATF6, activating transcription factor 6; Bad, Bcl-2-associated death promoter; Bax, Bcl-2-associated X protein; Bcl-2, B-cell CLL/lymphoma 2; Bim, Bcl-2 interacting mediator; BiP, binding immunoglobin protein; BNIP3, Bcl-2/adenovirus E1B 19 kDa-interacting protein 3; CHOP, C/EBP homologous protein; elF2 $\alpha$, eukaryotic initiation factor $2 \alpha$; ER, endoplasmic reticulum; HIF- $1 \alpha$, hypoxia-inducible factor-1 $\alpha$; IRE-1, inositol-requiring endonuclease-1; MBECs, mouse brain endothelial cells; MEFs, mouse embryonic fibroblasts; Min6, mouse insulinoma cell line 6; PERK, PKR-like ER kinase; PUMA, p53 upregulated modulator of apoptosis; shRNA, short hairpin RNA; siRNA, small interfering RNA; TUNEL, terminal dUDP nick-end labeling; UPR, unfolded protein response; XBP-1, X-box binding protein-1

Received 09.2.12; revised 18.4.12; accepted 02.5.12; Edited by M Federici
} 
the unfolded protein response (UPR) in a HIF-independent manner. ${ }^{5-9}$

In mammalian cells, ER stress causes activation of the ER stress sensors, PKR-like ER kinase (PERK), inositol-requiring endonuclaease-1 (IRE-1) and activating transcription factor 6 (ATF6). These are ER-resident transmembrane proteins that are able to sense the protein folding status in the ER by dissociation of immunoglobin binding protein binding immunoglobin protein (BiP). ER stress sensors are activated by phosphorylation (PERK and IRE-1) or transport to the Golgi (ATF6). The PERK pathway attenuates protein translation as an early response to alleviate ER stress. The transcription factors induced by UPR, activating transcription factor 4 (ATF4), X-box binding protein-1 (XBP-1) and ATF6 upregulate the expression of ER chaperon genes, ER-associated degradation components and genes that maintain ER homeostasis. ${ }^{10}$ When UPR fails to restore ER homeostasis cells undergo apoptosis through activation of the mitochondrial cell death pathway. ${ }^{11}$

In the present study we show that, in contrast to cancer cells, exposure of pancreatic $\beta$-cells to acute hypoxia of $1 \% \mathrm{O}_{2}$ leads to ER stress and apoptosis via the mitochondrial cell death pathway. Hypoxia-induced ER stress upregulates the pro-apoptotic transcription factor C/EBP homologous protein (CHOP). The key role of $\mathrm{CHOP}$ in this response was highlighted by the rescue of $\beta$-cells from hypoxia-induced apoptotic cell death in CHOP-knockdown cells. Finally, we show that pancreatic islets of type $2 \mathrm{db} / \mathrm{db}$ diabetic mice are hypoxic when compared with islets of normoglycemic mice, suggesting that hypoxia may contribute to $\beta$-cell dysfunction and cell loss occurring in type 2 diabetes.

\section{Results}

Culture of isolated pancreatic islets at normoxia leads to intracellular hypoxia and cell death. To investigate the impact on intracellular hypoxia of culturing isolated pancreatic islets at normal oxygen levels we have assessed the formation of pimonidazole adducts by immunoblot analysis. Our results show that pancreatic mouse islets kept at normoxia for $24 \mathrm{~h}$ following isolation presented intracellular hypoxia as indicated by the formation of pimonidazole adducts (Figure 1a). Staining of islets with an antibodyrecognizing pimonidazole adducts demonstrated that the central region of an isolated mouse islet becomes hypoxic after $24 \mathrm{~h}$ in culture (Figure $1 \mathrm{~b}$ ). Culturing of pancreatic islets for $24 \mathrm{~h}$ also compromises cell viability. As shown in Figure $1 \mathrm{c}$ islets cultured for $24 \mathrm{~h}$ presented a higher number of dead cells in the center of the islets when compared with the islets at time point $0 \mathrm{~h}$ (Figure 1a). These results demonstrate a correlation between hypoxia and cell death in the islet cells.

Exposure of Min6 cells to hypoxia induces apoptosis. Although several studies have investigated the impact of hypoxia-induced $\beta$-cell death upon islet transplantation, ${ }^{4}$ the underlying mechanism of $\beta$-cell death has not yet been unraveled. To investigate whether hypoxia induces apoptosis of pancreatic $\beta$-cells we exposed the mouse insulinoma cell

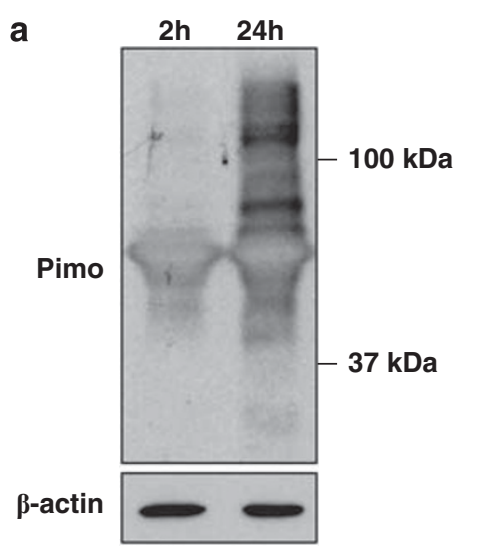

b
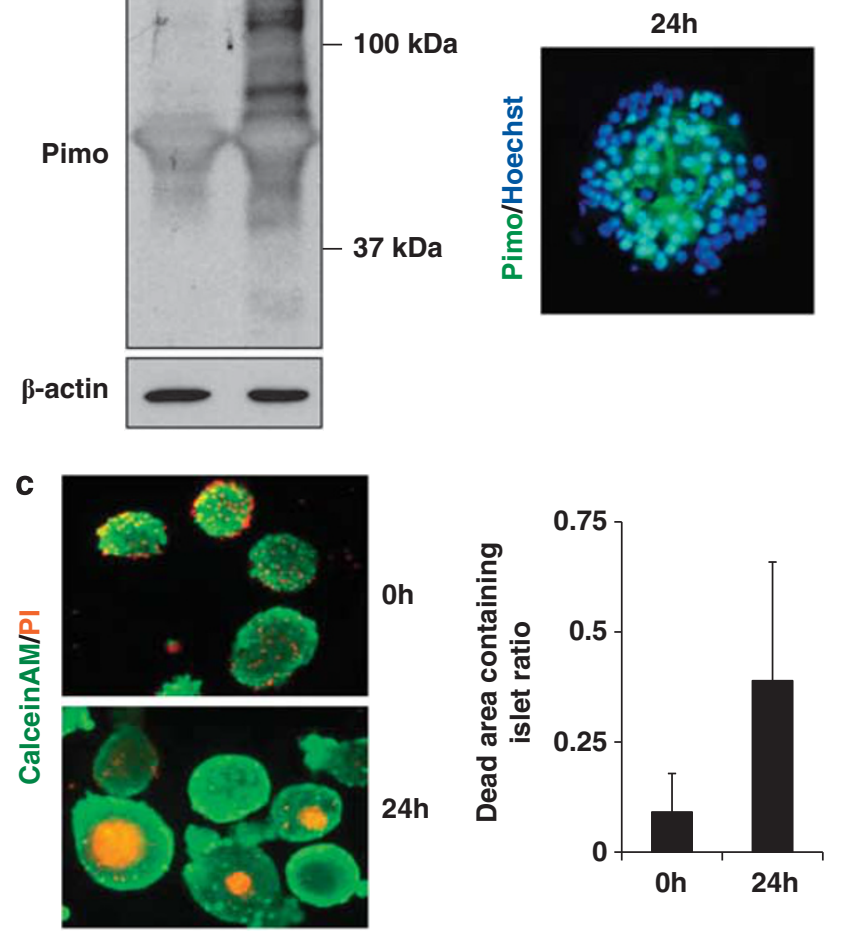

Figure 1 Intracellular hypoxia and impaired cell viability is observed in pancreatic islets cultured at normoxia for $24 \mathrm{~h}$ following isolation. (a) Twenty-four hours of culture following isolation of pancreatic islets leads to intracellular hypoxia. Whole-cell extracts were prepared from pancreatic islets cultured at normoxia for 2 or $24 \mathrm{~h}$. Isolated islets were treated with $10 \mu \mathrm{M}$ of pimonidazole for $2 \mathrm{~h}$ before lysis. Proteins were separated by SDS-PAGE and analyzed by immunoblotting with antipimonidazole adduct (Pimo) and anti- $\beta$-actin antibodies. (b) $\beta$-Cells in the center of pancreatic islets became hypoxic after $24 \mathrm{~h}$ in culture. Isolated islets were stained with anti-pimonidazole adduct antibody (Pimo) and nuclei were counterstained with Hoechst 33342. (c) Twenty-four hours after isolation of mouse pancreatic islets the presence of dead cells is detected in the center of the islet. Islets were stained with calcein-AM and propidium iodide (PI)

line $6(\text { Min6 })^{12}$ or primary mouse brain endothelial cells (MBECs) to $1 \% \mathrm{O}_{2}$ (hypoxia). Our results show that $24 \mathrm{~h}$ of hypoxia induces apoptosis in Min6 cells as illustrated by the detection of TUNEL (terminal dUDP nick-end labeling)stained cells. In contrast to Min6 cells, no TUNEL-positive cells were observed in MBECs (Figure 2a). FACS analysis of cells stained in the TUNEL assay showed that 11 or $55 \%$ of cells undergo apoptosis after 8 or $24 \mathrm{~h}$ of hypoxia, respectively (Supplementary Figure 1). As expected, in both Min6 and MEBCs, HIF-1 $\alpha$ protein levels were increased in response to hypoxia (Figure 2b). ${ }^{13,14}$ In Min6 cells, active caspase- 3 was detected after $2 \mathrm{~h}$ of hypoxia treatment, and the induction peaked at $8 \mathrm{~h}$, indicating that commitment of Min6 cells to apoptosis occurs after a short period of exposure to hypoxia. Treatment of Min6 cells and MBECs with the apoptosis inducer staurosporine upregulated cleavage of caspase-3 (Figure $2 \mathrm{~b}$ ). In contrast to staurosporine, treatment with the ER stress inducer thapsigargin only upregulated active caspase-3 levels in Min6 cells indicating that $\beta$-cells are more sensitive to ER stress-induced 
a
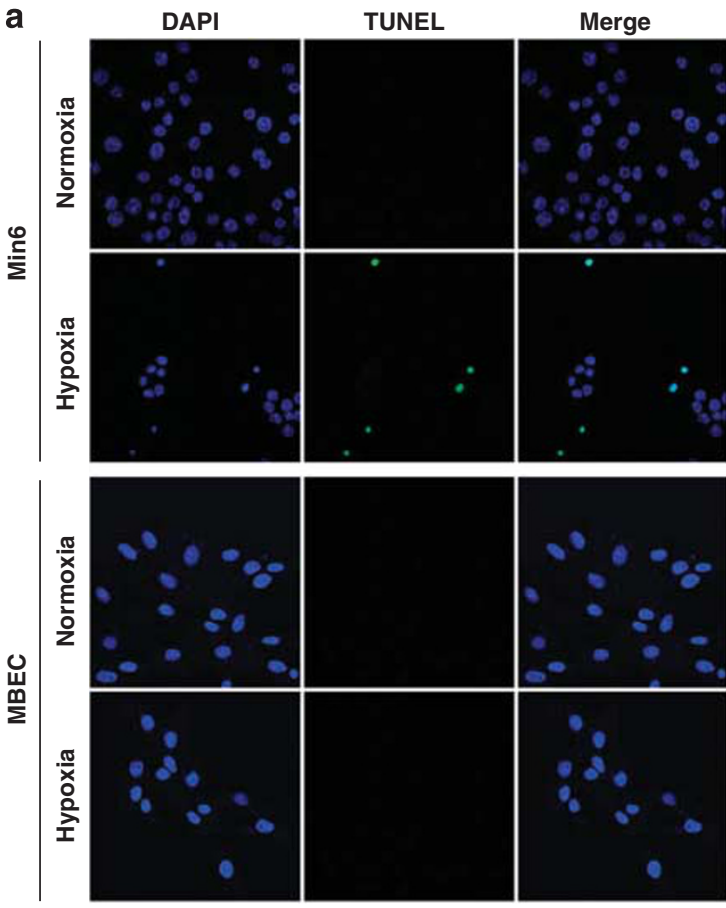

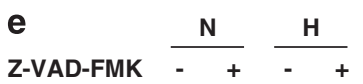

HIF-1 $\alpha$

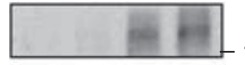

Cleaved

Casp-3

$\beta$-actin

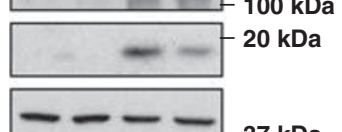

b

$\frac{\text { Min6 }}{\text { Hypoxia(h) }}$

(1)

MBEC
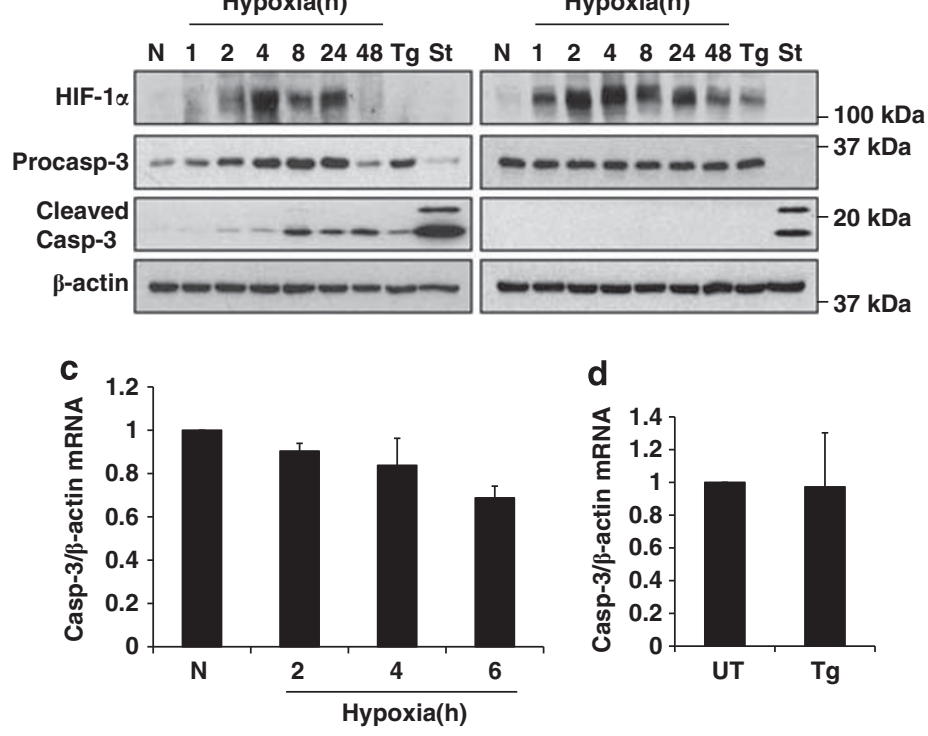

d
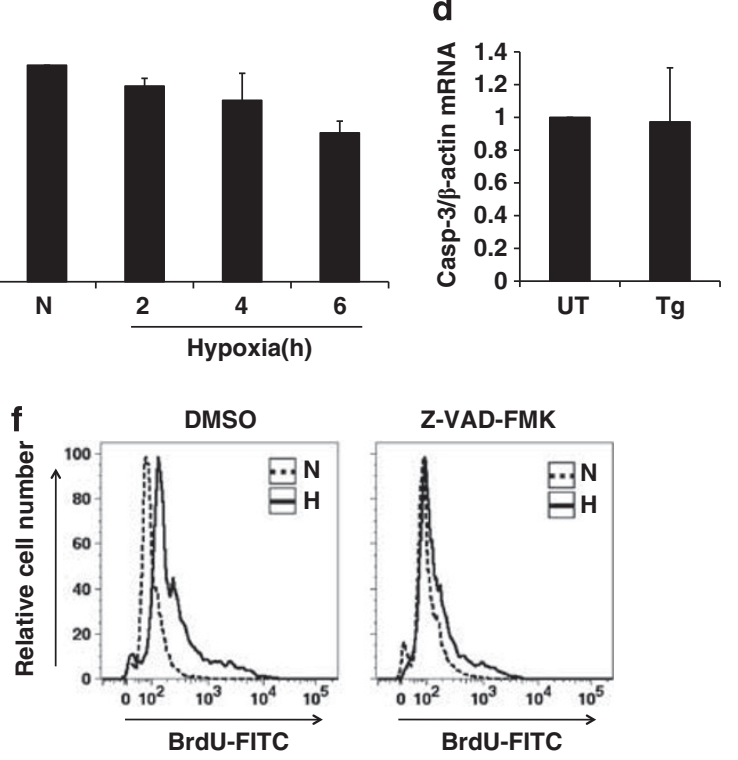

Z-VAD-FMK

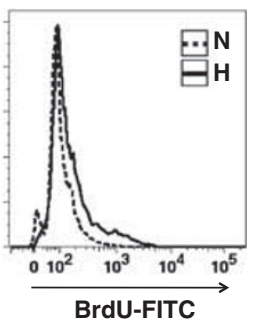

Figure 2 Exposure to $1 \% \mathrm{O}_{2}$ induces apoptosis in Min6 cells. (a) Min6 cells undergo apoptosis after $24 \mathrm{~h}$ of hypoxia. Apoptosis was assessed by TUNEL assay in Min6 cells and MBECs. (b) Active caspase-3 accumulates in Min6 cells in response to $8 \mathrm{~h}$ of hypoxia treatment. Min6 cells and MBECs were exposed to hypoxia for the indicated time points or kept at normoxia. Cells were treated during $8 \mathrm{~h}$ with $1 \mu \mathrm{M}$ thapsigargin $(\mathrm{Tg})$, or $1 \mu \mathrm{M}$ staurosoporine (St). Whole-cell extract proteins were separated by SDSPAGE and analyzed by immunoblotting with anti-HIF- $1 \alpha$, anti-procaspase-3 (Procasp-3), anti-active caspase-3 (Cleaved Casp-3) and anti- $\beta$-actin antibodies. (c) Caspase-3 mRNA levels were not induced by exposure to $1 \% \mathrm{O}_{2}$. (d) Caspase-3 mRNA levels remained unchanged following thapsigargin (Tg) treatment $(8 \mathrm{~h}, 1 \mu \mathrm{m}$ of thapsigargin). (c and d) Caspase-3 mRNA levels were assessed qRT-PCR and normalized to $\beta$-actin ( $n=4$; values are mean \pm S.D.) (e) Treatement of Min6 cells with the pan-caspase inhibitor Z-VAD-FMK inhibits caspase-3 activation. Min6 cells were kept in normoxia or expose to hypoxia for $24 \mathrm{~h}$ in presence or absence of the pan-caspase inhibitor Z-VADFMK $(20 \mu \mathrm{M})$. Whole-cell extract proteins were separated by SDS-PAGE and analyzed by immunoblotting with anti-HIF-1 $\alpha$, anti-active caspase-3 (Cleaved Casp-3) and anti- $\beta$-actin antibodies. (f) Inhibition of caspase activity by the pan-caspase inhibitor Z-VAD-FMK rescue Min6 cells from hypoxia-induced apoptosis. Min6 cells were kept in normoxia or expose to hypoxia for $24 \mathrm{~h}$ in presence or absence of the pan-caspase inhibitor Z-VAD-FMK (20 $\mu \mathrm{M})$. Apoptosis was assessed by the quantification of BrdU-FITC-labeled DNA breaks (BrdU-FITC) using a flow cytometry-based TUNEL assay

apoptosis than the endothelial cells used in this study. In contrast to caspase-3 protein levels, mRNA levels of CASP3 were not induced by hypoxia or thapsigargin (Figures 2c and 2d) and exposures longer than $4 \mathrm{~h}$ of hypoxia downregulated expression of the CASP3 gene (Supplementary Figure 2a). To assess the contribution of caspase-3 activity to hypoxia-induced apoptosis, we have treated Min6 cells with the pan-caspase inhibitor Z-VAD-FMK and performed FACS analysis to quantify TUNEL-positive cells. Treatment of Min6 cells with Z-VAD-FMK inhibited caspase-3 activation (Figure 2e) As demonstrated in Figure $2 f$ inhibition of caspase activity rescued Min6 cells from hypoxia-induced apoptosis (from $49.9 \%$ in untreated cells to $28.2 \%$ in Z-VAD-FMK-treated cells). In conclusion, these results show that Min6 cells undergo apoptosis in response to acute hypoxia of $1 \% \mathrm{O}_{2}$ and activation of caspase- 3 is required for the apoptotic cell death.

HIF-1 $\alpha$ does not contribute to hypoxia-dependent apoptosis in Min6 cells. Earlier studies have suggested that HIF-1 $\alpha$ could participate in hypoxia-mediated apoptosis by stabilizing p53 or by upregulating the pro-apoptotic regulator BNIP3. ${ }^{15}$ Expression of HIF- $1 \alpha$ has also been shown to colocalize topographically with active caspase-3 in the pancreatic islets indicating a correlation between HIF- $1 \alpha$ expression and $\beta$-cell apoptosis. ${ }^{13}$ In this context, we have investigated the role of HIF- $1 \alpha$ in hypoxia-induced apoptosis in Min6 cells. To this end we used lentivirus delivery to generate stable cells expressing short hairpin RNAs (shRNAs) specifically targeting HIF-1 $\alpha$ expression. 

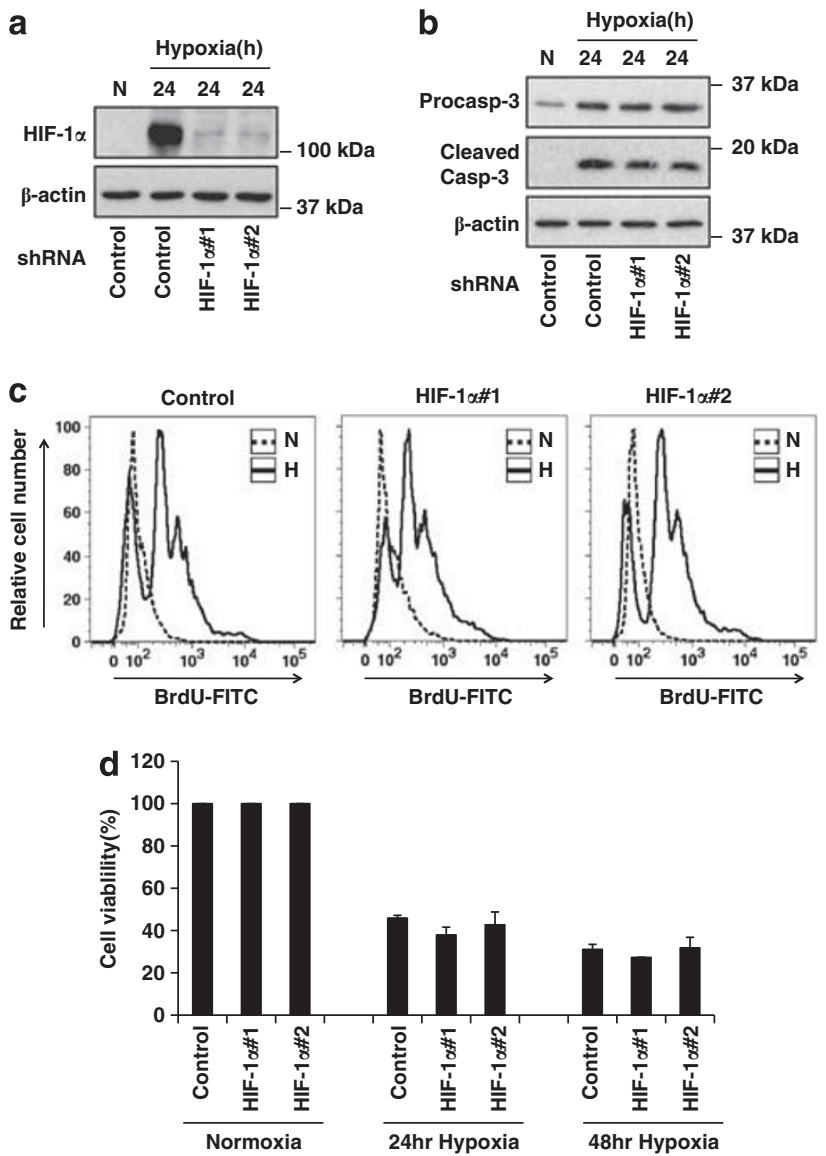

Figure 3 Apoptosis induced by exposure to $1 \% \mathrm{O}_{2}$ in Min6 cells is independent of HIF- $1 \alpha$. Min6 cells stably expressing a negative control shRNA (control) or shRNAs targeting HIF-1 $\alpha$ (HIF-1 $\alpha \# 1$ and HIF-1 $\alpha \# 2$ ) were generated by lentivirus delivery. (a) HIF-1 $\alpha$ protein levels in stable cell lines. Whole-cell extract proteins were separated by SDS-PAGE and analyzed by immunoblotting with an anti-HIF- $1 \alpha$ antibody. $\beta$-Actin levels were analyzed as a loading control. (b) Hypoxia-mediated cleavage of caspase-3 in Min6 cells is HIF-1 $\alpha$ independent. Whole-cell extract proteins were separated by SDS-PAGE and analyzed by immunoblotting with antiprocaspase-3 (procasp-3), anti-cleaved caspase-3 (cleaved Casp-3) and anti- $\beta$ actin antibodies. (c) Hypoxia-induced apoptosis in Min6 cells is HIF-1 $\alpha$ independent. Stable Min6 knockdown cell lines were cultured under normoxia or hypoxia for $48 \mathrm{~h}$. Apoptosis was assessed by quantification of BrdU-FITC-labeled DNA breaks (BrdUFITC) using a flow cytometry-based TUNEL assay. (d) HIF-1 $\alpha$ does not contribute to the reduced cell viability observed under hypoxia treatment. Stable cell lines were cultured at normoxia or subjected to hypoxia for the indicated time points. Cell viability was measured as described (see Materials and Methods)

Successful HIF-1 $\alpha$ knockdown was achieved in two different cell lines named HIF-1 $\alpha \# 1$ and HIF-1 $\alpha \# 2$ (Figure $3 a$ and Supplementary Figures $3 a$ and $b$ ). In these cell lines hypoxiainduced upregulation of procaspase-3 and active caspase-3 demonstrating that induction of apoptosis is not HIF- $1 \alpha$ dependent. FACS analysis of cells stained by TUNEL showed that apoptosis in HIF- $1 \alpha$ knockdown stable cells was not significantly distinct from control cells (control cells: $63.2 \%$, stable cell line HIF-1 1 \#1: $64.2 \%$, and HIF-1 $\alpha \# 2$ : $68.7 \%$ TUNEL positive; Figure 3c). Cell viability was also assessed, and we observed that there was no significant difference between control and HIF-1 $\alpha$ knockdown cells following hypoxia treatment at different time points (Figure $3 \mathrm{~d}$ ). The role of HIF-2 $\alpha$ in the apoptotic response was not investigated because previous studies have indicated that mouse $\beta$-cells do not express HIF- $2 \alpha{ }^{16}$ Consistent with these observations, we have failed to detect the HIF-2 $\alpha$ transcript in Min6 cells (data not shown). In conclusion, our results show that HIF-1 $\alpha$ does not contribute to apoptosis or apoptosis-independent cell death induced by exposure of Min6 cells to $1 \% \mathrm{O}_{2}$.

Hypoxia activates the UPR in the pancreatic $\beta$-cell line Min6. Induction of ER stress leads to activation of UPR to restore ER homeostasis. However, when ER stress is not resolved UPR-dependent pathways will lead to apoptosis. ${ }^{11}$ As we have observed that hypoxia induces apoptosis of Min6 cells by a HIF- $1 \alpha$-independent mechanism we investigated whether exposure of the cells to $1 \% \mathrm{O}_{2}$ activated the UPR. One of the first events in response to ER stress is PERKmediated phosphorylation of the translation initiation factor eukaryotic initiation factor $2 \alpha$ (elF $2 \alpha$ ) leading to the reduction of global protein synthesis and preferential translation of selected mRNAs including ATF4. ${ }^{10,17}$ Our results show that in Min6 cells, but not in MEBCs, phosphorylated levels of elF2 $\alpha$ were upregulated and peaked at $8 \mathrm{~h}$ of hypoxia treatment (Figure 4a). Protein levels of ATF4 were also increased in response to hypoxia. Between 1 and $48 \mathrm{~h}$ of hypoxia ATF4 levels were upregulated above the levels observed in normoxic cells with the induction peaking at 2, 4 and $48 \mathrm{~h}$ of exposure (Figure $4 \mathrm{a}$ ). ATF4 mRNA levels were also induced with the peak at $4 \mathrm{~h}$ of hypoxia exposure (twofold; Figure 4f). In contrast to the induction observed at 2-6h, long exposure to hypoxia (24 or $48 \mathrm{~h}$ ) led to downregulation of ATF4 gene expression (Supplementary Figure $2 b$ ). These results demonstrate that the PERK/elF2 $\alpha /$ ATF4 branch of the UPR is activated by exposure to $1 \% \mathrm{O}_{2}$ in Min6 cells, and that high levels of ATF4 protein are sustained during hypoxia treatment.

The involvement of IRE-1/XBP-1 branch of the UPR was also investigated. In Min6 cells, the activated IRE-1 protein accumulates at 2 and $4 \mathrm{~h}$ of hypoxia (Figure $4 \mathrm{~b}$ ), whereas the spliced form of XBP-1 is detected at 4 and $8 \mathrm{~h}$ of hypoxia (Figure 4c) indicating that the IRE-1/XBP-1 branch of the UPR is also activated in response to $1 \% \mathrm{O}_{2}$.

The third branch of UPR is mediated by ATF6. Our results show that cleavage of ATF6 was induced by hypoxia in Min6 cells, resulting in depletion of the $90-\mathrm{kDa}$ uncleaved form and appearance of the 50-kDa cleaved form of ATF6 (Figure 4d). The cleaved form of ATF6 is detected after $1 \mathrm{~h}$ of hypoxia and accumulates during the first $8 \mathrm{~h}$ of treatment consistent with activation of the ATF6 branch of the UPR in Min6 cells exposed to $1 \%$ hypoxia.

Together these pathways upregulate the transcription of UPR target genes such as the ER chaperon BiP, which will contribute to the restoration of protein folding homeostasis. ${ }^{18}$ Our results show that protein levels of BiP were upregulated by hypoxia in Min6 cells (Figure 4e). However, although we observed increased expression or activation of the three UPR transcription factors ATF4, XBP-1 and ATF6 known to induce BiP gene expression, ${ }^{19,20}$ BiP mRNA levels were not upregulated in response to hypoxia (Figure 4i). 
a

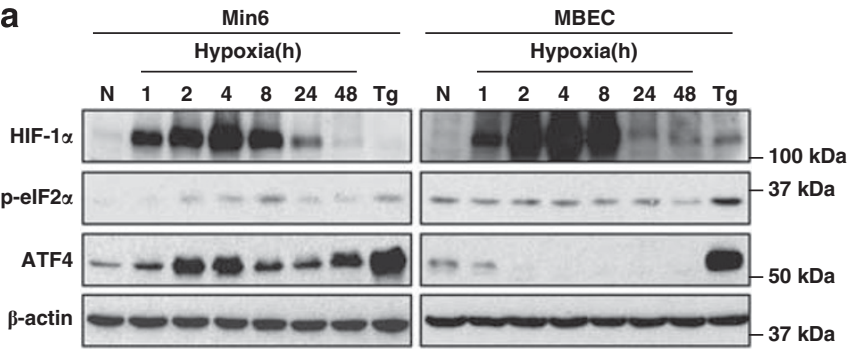

b

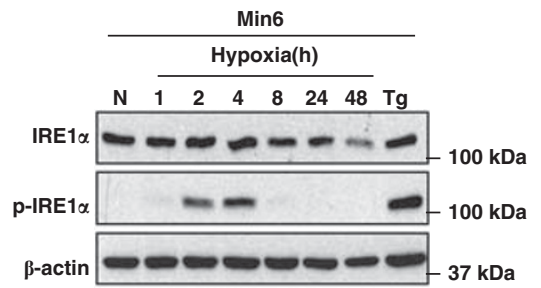

C

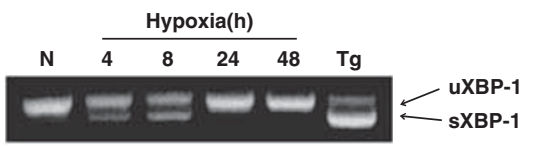

d

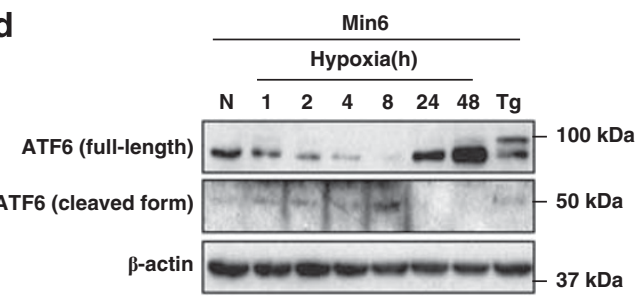

e
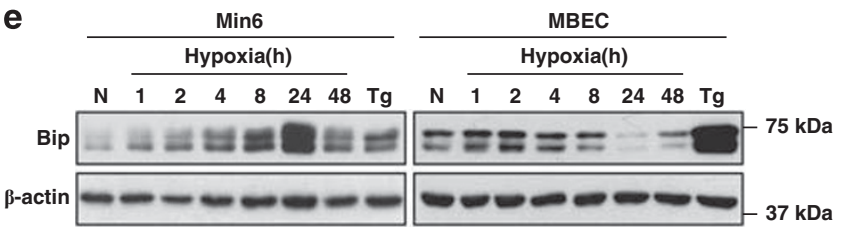
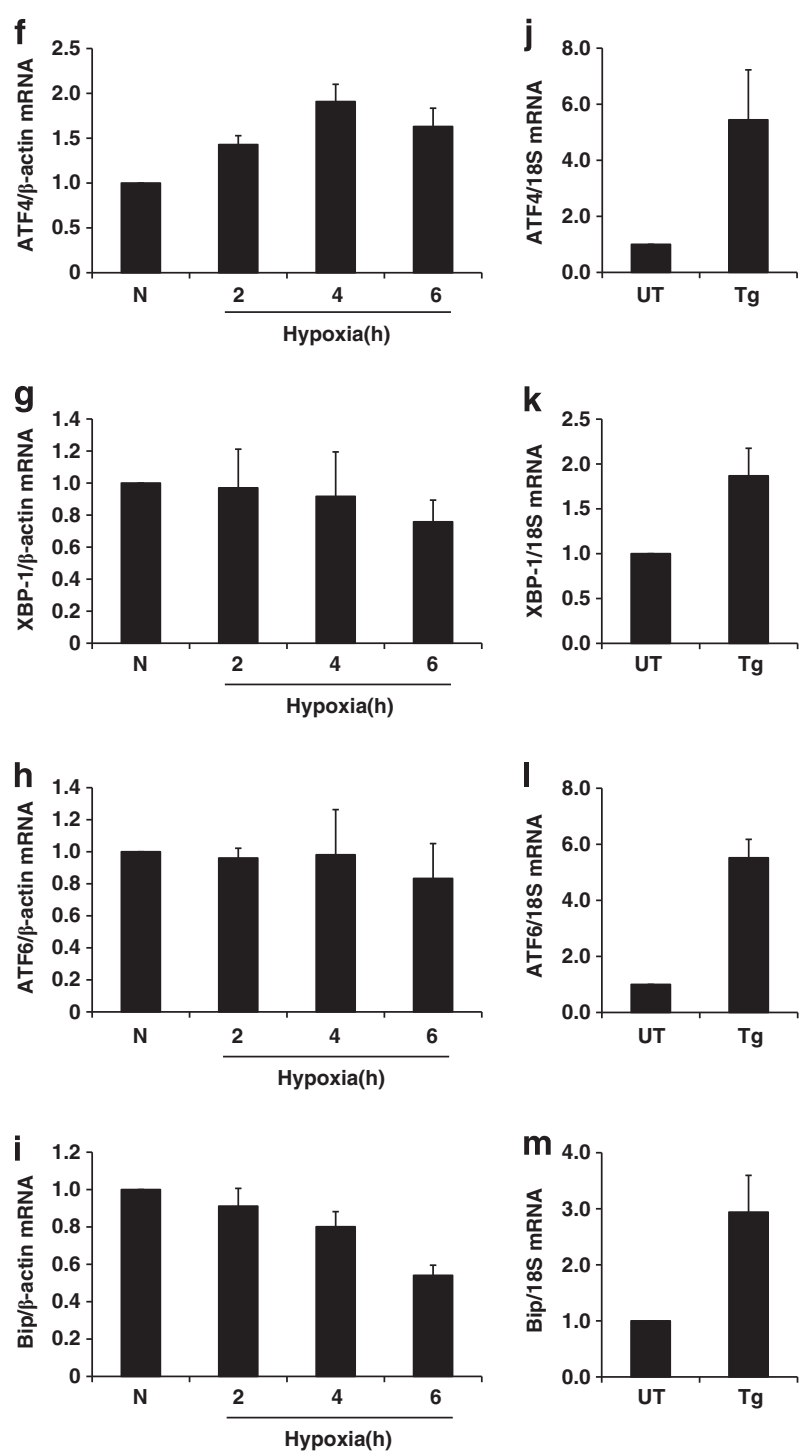

Figure 4 Exposure to $1 \% \mathrm{O}_{2}$ activates the three branches of the UPR in Min 6 cells. (a) Hypoxia induces phosphorylation of elF2 $\alpha$ and upregulates ATF4 protein levels in Min6 cells. (b) Hypoxia induces phosphorylation of IRE1 $\alpha$ in Min6 cells. (c) Splicing of XBP-1 mRNA in Min6 cells is induced by hypoxia. PCR analysis for unspliced (uXBP-1) or spliced (sXBP-1) forms of XBP-1 was performed. (d) Cleavage of ATF6 in Min6 cells is upregulated by hypoxia. (e) Protein levels of BiP were upregulated by hypoxia in Min6 cells but not in MBECs. (a, b, d and e) Whole-cell extracts were prepared, and proteins were separated by SDS-PAGE and analyzed by immunoblotting with anti-HIF-1 $\alpha$ (a), anti-phosphorylated elF2 $\alpha(\mathrm{p}$-elF2 $\alpha)(\mathbf{a})$, anti-ATF4 (a), anti-IRE1 $\alpha(\mathbf{b})$, anti-phosphorylated IRE1 $\alpha(\mathrm{p}-\mathrm{IRE} 1 \alpha)(\mathbf{b})$, anti-ATF6 full-length and cleaved form (d), anti-BiP (e) and anti- $\beta$-actin antibodies. Impact of hypoxia on mRNA levels of ATF4 (f), XBP-1 (g), ATF6 (h) and BiP (i). Min6 cells were cultured at normoxia or hypoxia at indicated time points. mRNA expression levels were measured by qRT-PCR and normalized to $\beta$-actin ( $n=4$; values are mean \pm S.D.). Regulation of mRNA levels of ATF4 (j), XBP-1 (k), ATF6 (I) and BiP ( $\mathbf{m})$ in response to thapsigargin treatment. Min6 cells were kept untreated (UT) or treated with $1 \mu \mathrm{M}$ thapsigargin for $8 \mathrm{~h}$. Expression levels were measured by qRT-PCR and normalized to $18 \mathrm{~S}$ RNA ( $n=4$; values are mean \pm S.D.)

Treatment of Min6 cells with thapsigargin showed that both protein and mRNA levels of components of the UPR pathways were positively regulated by the ER stress inducer in Min6 cells (Figures $3 a-e$ and $j-m$ ). In contrast to thapsigargin, hypoxia treatment inhibited mRNA expression of XBP-1, ATF6 and BiP genes (Figures 3g-i; Supplemetary Figure $2 \mathrm{~b}$ ) indicating that, although the UPR pathway is activated by $1 \%$ $\mathrm{O}_{2}$ in Min6 cells, the induced mechanism does not trigger the same response as thapsigargin.

Hypoxia changes levels of expression of several Bcl-2 family proteins in Min6 cells. B-cell CLL/lymphoma 2
(Bcl-2) family proteins have a pivotal role in the induction of apoptosis in response to ER stress. ${ }^{21}$ We therefore examined the impact of hypoxia on the expression levels of several proteins of the Bcl-2 family. As shown in Figure $5 \mathrm{a}$, levels of Bcl-2 family members were unchanged in MBECs, whereas in Min6 cells, the levels of the pro-apoptotic proteins p53 upregulated modulator of apoptosis (PUMA), Bad and $\mathrm{Bcl}-2$-associated $\mathrm{X}$ protein (Bax) were elevated after $8 \mathrm{~h}$ of hypoxia treatment. To further investigate whether Bad is activated in response to hypoxia, we have assessed protein levels of phosphorylated-Bad. Our results show that Ser ${ }^{112}$ of Bad was completely dephosphorylated after $8 \mathrm{~h}$ of hypoxia 
(Figure 5a). Dephosphorylation of Bad occurs as early as $2 \mathrm{~h}$ of hypoxia and was inhibited at late time points of treatment (24-48 h; Figure 5a and Supplementary Figure 4). Regulation of $\mathrm{Bcl}-2$ interacting mediator $(\mathrm{Bim})$ in response to hypoxia presented a more complex pattern of regulation

a
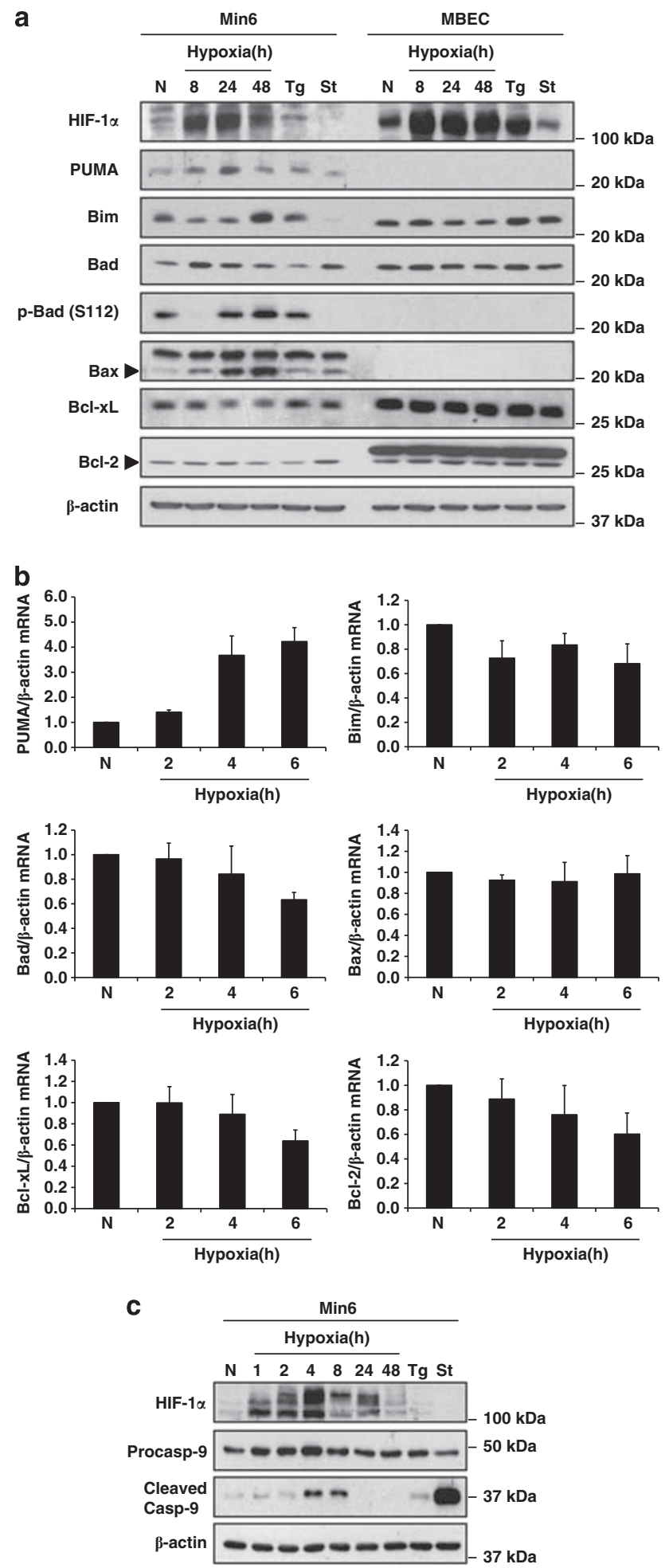

with an accumulation of the protein at $1-2 \mathrm{~h}$ of treatment (Supplementary Figure 4) and a second peak of induction at $48 \mathrm{~h}$ (Figure 5a). Hypoxia also downregulated protein levels of the anti-apoptotic protein $\mathrm{Bcl}-\mathrm{xL}$ at early time points whereas $\mathrm{Bcl}-2$ levels were slightly reduced after $48 \mathrm{~h}$ of treatment. mRNA expression of $\mathrm{Bcl}-2$ family proteins was also analyzed. Only PUMA and Bim mRNA levels were induced by hypoxia. Time points of PUMA upregulation correlated positively with the time course upregulation of protein levels (Figure $5 \mathrm{~b}$ ), indicating that PUMA is transcriptionally induced by hypoxia. In contrast to PUMA, Bim mRNA levels were only induced at $48 \mathrm{~h}$ of hypoxia indicating that Bim is regulated at transcriptional and post-transcriptional levels. In contrast to PUMA and Bim, the other genes analyzed were downregulated or remained unchanged in response to hypoxia indicating that Bad and Bax are posttranscriptionally regulated. Activation of the ER located caspase-12 was not observed in Min6 cells (Supplementary Figure 5).

To demonstrate the involvement of the intrinsic apoptotic pathway we have investigated whether hypoxia activates caspase- 9 in Min 6 cells. Our results show that treatment of the cells with $4-8 \mathrm{~h}$ of hypoxia led to accumulation of cleaved caspase-9 (Figure $5 \mathrm{c}$ ), indicating activation of the mitochondrial apoptotic pathway.

Regulation of CHOP by hypoxia in Min6. CHOP has been identified as an ER stress-induced transcription factor that is a significant mediator of apoptosis in response to ER stress. ${ }^{22,23}$ We therefore examined the impact of hypoxia treatment on CHOP expression in Min6 cells. As shown in Figure $6 \mathrm{a}$, protein levels of $\mathrm{CHOP}$ were upregulated by hypoxia in Min6 cells, but not in endothelial cells. In Min6 cells, protein accumulation was increased in a time-dependent manner from 4 to $24 \mathrm{~h}$ of hypoxia treatment. Increased protein levels correlated with induction of $\mathrm{CHOP}$ gene expression (Figure 6b). As expected, thapsigargin upregulated protein and mRNA levels of CHOP (Figures $5 \mathrm{a}$ and c). ${ }^{24}$

Induction of $C H O P$ gene expression has been shown to be primarily mediated by the PERK/eIF2 $\alpha /$ ATF4 UPR pathway, although contribution of the other two other arms of the UPR

Figure 5 Regulation of $\mathrm{Bcl}-2$ family proteins by hypoxia in Min6 cells and MBECs. (a) Hypoxia changes protein levels of several Bcl-2 family proteins. Min6 cells and MBECs were cultured in normoxia or exposed to hypoxia $\left(1 \% \mathrm{O}_{2}\right)$ for the indicated time points. Cells were treated during $8 \mathrm{~h}$ with $1 \mu \mathrm{M}$ thapsigargin $(\mathrm{Tg})$, or $1 \mu \mathrm{M}$ staurosporine (St). Whole-cell extracts were prepared, and proteins were separated by SDS-PAGE. Levels of HIF- $1 \alpha$, PUMA, Bim, Bad, phosphorylated-Bad ( $\mathrm{p}$-Bad S112), Bax, Bcl-xL, Bcl-2 and $\beta$-actin were assessed by immunoblotting using specific antibodies recognizing these proteins. PUMA, phosphorylated-Bad and Bax are not recognized in MBECs by these antibodies. (b) Impact of hypoxia on mRNA levels of $\mathrm{Bcl}-2$ family of proteins. Min6 cells were cultured at normoxia or hypoxia $\left(1 \% \mathrm{O}_{2}\right)$ at indicated time points. Expression levels of PUMA, Bim, Bad, Bax, Bcl-xL and Bcl-2 mRNA were measured by qRT-PCR and normalized to $\beta$-actin $(n=4$; values are mean \pm S.D.). (c) Caspase- 9 is activated by hypoxia in Min6 cells. Whole-cells extract proteins were separated by SDS-PAGE and analyzed by immunoblotting with anti-HIF-1 $\alpha$, anti-procaspase-9, anti-cleaved caspase- 9 and anti- $\beta$-actin antibodies 
a
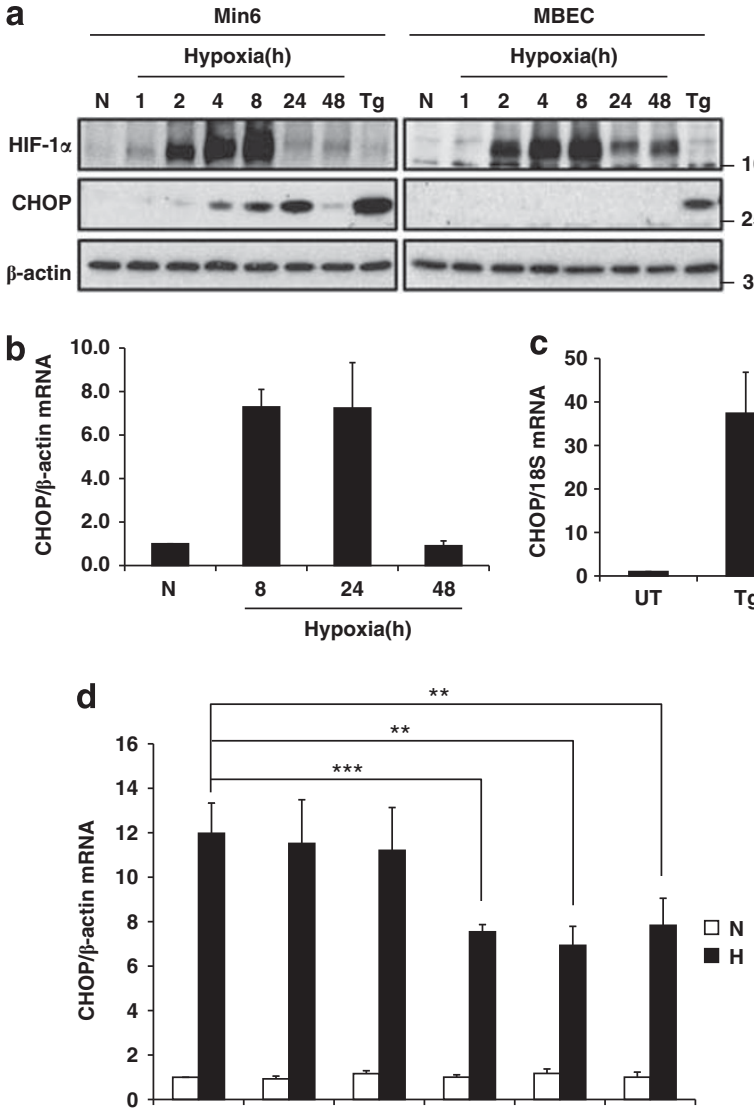

siRNA Control HIF-1 $\alpha$ Arnt ATF4 XBP-1 ATF6

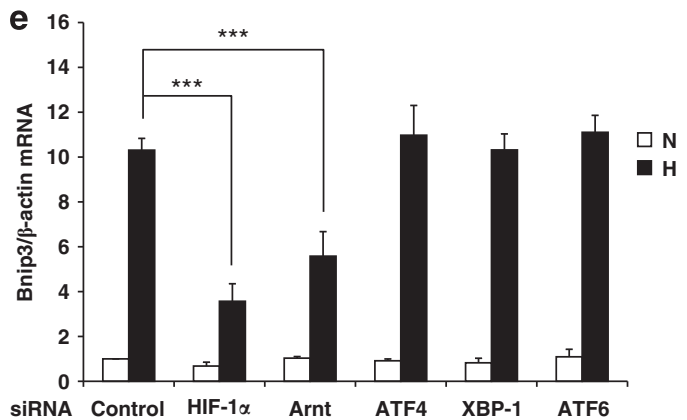

Figure 6 CHOP expression is upregulated by hypoxia in Min6 cells. (a) Hypoxia induces CHOP protein levels in Min6 cells. Whole-cell extract proteins were separated by SDS-PAGE and analyzed by immunoblotting with anti-HIF-1 $\alpha$, anti$\mathrm{CHOP}$ and anti- $\beta$-actin antibodies. (b) CHOP gene expression is upregulated by exposure to $1 \% \mathrm{O}_{2}$ in Min6 cells. Cells were cultured at normoxia or subjected to hypoxia $\left(1 \% \mathrm{O}_{2}\right)$ for the indicated time points. Expression levels of CHOP mRNA were measured by qRT-PCR and normalized to $\beta$-actin $(n=4$; values are mean \pm S.D.). (c) Induction of CHOP gene expression by thapsigargin. Min6 cells were kept untreated (UT) or treated with $1 \mu \mathrm{M}$ thapsigargin for $8 \mathrm{~h}$. Expression levels of CHOP mRNA were measured by qRT-PCR and normalized to 18S RNA $(n=4$; values are mean \pm S.D.). (d) Upregulation of CHOP gene expression by hypoxia $\left(1 \% \mathrm{O}_{2}\right)$ in Min6 cells is mediated by the three UPR transcription factors ATF4, XBP-1 and ATF6. Min6 cells were transiently transfected with a control siRNA or specific siRNAs against HIF- $1 \alpha$, Arnt, ATF4, XBP-1 and ATF6. $48 \mathrm{~h}$ after transfection, cells were exposed to hypoxia for $24 \mathrm{~h}$ or kept at normoxia. (e) UPR transcription factors have no effect on hypoxia-dependent induction of the HIF- $1 \alpha$ target gene BNIP3. Expression levels of CHOP and BNIP3 mRNAs were measured by qRT-PCR and normalized to $\beta$-actin $\left(n=5\right.$; values are mean \pm S.D.; ${ }^{* \star} P<0.05$; ${ }^{\star \star \star} P<0.005$ relative to control by two-tailed Student's $t$ test) pathway has also been suggested. ${ }^{25,26}$ We therefore investigated the contribution of each UPR branch to $C H O P$ gene induction by using small interfering RNAs (siRNAs) targeting the corresponding UPR transcription factors. In parallel we also transiently silenced HIF- $1 \alpha$ and Arnt expression. The efficiency of knockdown of each transcription factor is shown in Supplementary Figures 6a-e. Silencing ATF4, XBP-1 or ATF6 expression significantly reduced hypoxia-dependent induction of CHOP mRNA levels, while silencing of HIF- $1 \alpha$ or Arnt had no impact on $\mathrm{CHOP}$ induction (Figure $6 \mathrm{~d}$ ). In contrast to $C H O P$, hypoxia-mediated induction of the HIF target genes BNIP3, GLUT1 and PGK1 was dependent on HIF-1 $\alpha$ and Arnt a

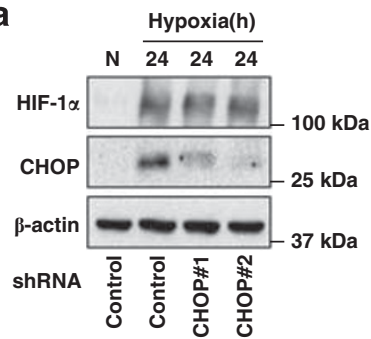

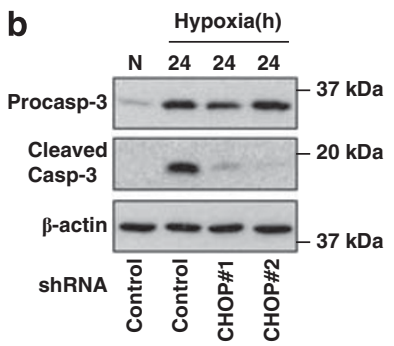

b
C
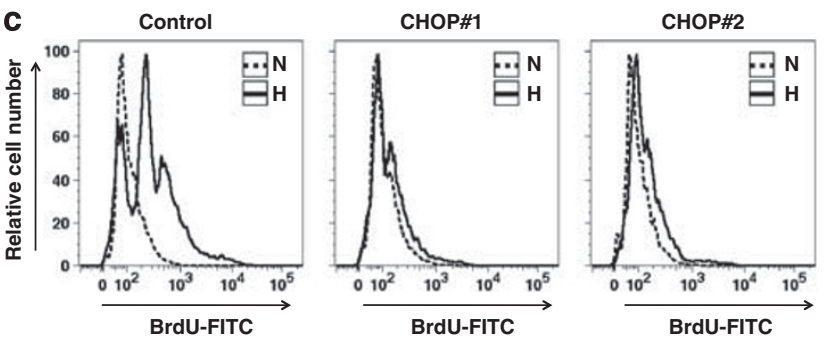

d
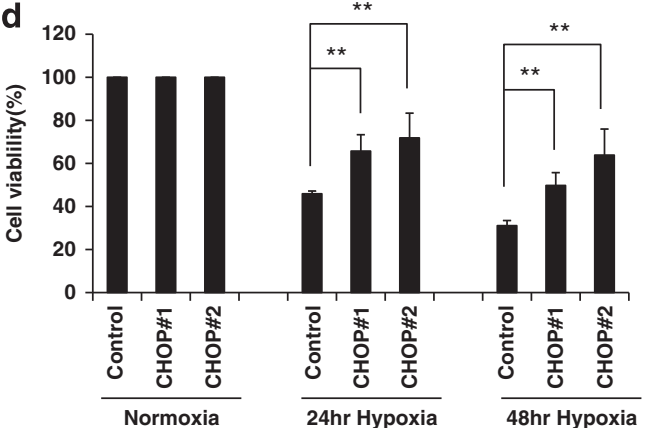

Figure 7 Hypoxia-induced apoptosis is CHOP dependent. Min6 cells stably expressing a negative control shRNA (C) or shRNAs targeting CHOP (CHOP\#1,

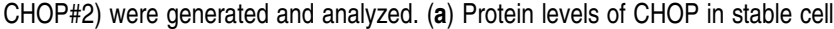
lines. HIF- $1 \alpha$ and $\mathrm{CHOP}$ protein levels were assessed by immunoblot analysis using anti-HIF- $1 \alpha$, anti-CHOP. (b) Cleavage of caspase-3 induced by exposure to $1 \% \mathrm{O}_{2}$ in Min6 cells is mediated by CHOP. Whole-cells extracts were prepared and proteins separated by immunoblotting using anti-procaspase-3 (procasp-3), anticleaved caspase- 3 (cleaved Casp-3) and anti- $\beta$-actin antibodies. (c) $\mathrm{CHOP}$ mediates hypoxia-induced apoptosis in Min6 cells. CHOP-knockdown cell lines were cultured under normoxia or hypoxia for $48 \mathrm{~h}$. Apoptosis was assessed by quantification of BrdU-FITC-labeled DNA breaks (BrdU-FITC) using a flow cytometry-based TUNEL assay. (d) CHOP contributes to the reduced cell viability observed at hypoxia. Min6 stable cell lines were cultured under normoxia or hypoxia $\left(1 \% O_{2}\right)$ for the indicated time points. Cell viability was measured $(n=3$; values are mean \pm S.D.; ${ }^{\star \star} P<0.05$ relative to control by two-tailed Student's $t$ test) 
and was insensitive to silencing of UPR transcription factors (Figure 6e, Supplementary Figures $6 f$ and g). These results show that the three branches of UPR contribute to upregulation of $C H O P$ in response to hypoxia of $1 \% \mathrm{O}_{2}$.

CHOP is the main mediator of hypoxia-induced apoptosis in Min6 cells. To investigate the contribution of $\mathrm{CHOP}$ to apoptosis induced by hypoxia in Min6 cells, we generated by lentivirus delivery stable cells expressing shRNAs specifically targeting CHOP expression. Efficient knockdown of $\mathrm{CHOP}$ was achieved in two different cell lines named CHOP\#1, and CHOP\#2 (Figure 7a). Upon $24 \mathrm{~h}$ of hypoxia treatment, the levels of active caspase- 3 were dramatically diminished in CHOP-knockdown cell lines when compared with control cells (Figure 6b). FACS analysis of cells stained by TUNEL showed that apoptosis induced by hypoxia was significantly decreased from $57.7 \%$ in control cells to $12.2 \%$ and $10.1 \%$ in CHOP\#1 and CHOP\#2 stable cell lines, respectively (Figure 7c), indicating that silencing $\mathrm{CHOP}$ expression rescued Min6 cells from apoptotic cell death. Cell viability was also partially rescued in CHOP-knockdown cells from $45.9 \%$ in control cells to 65.7 and $71.8 \%$ in CHOP\#1 and CHOP\#2 stable cell lines upon $24 \mathrm{~h}$ of exposure to hypoxia, or from 31.1 to $49.8 \%$ and $63.9 \%$ upon $48 \mathrm{~h}$ of exposure to hypoxia, respectively (Figure $7 \mathrm{~d}$ ). Considering that silencing $\mathrm{CHOP}$ expression only partially rescued Min6 cell viability at hypoxia, it is conceivable that other pathways contribute to hypoxia-induced cell death. In agreement with this hypothesis our studies show that LC3B-II protein levels were induced by hypoxia indicating upregulation of autophagy (Supplementary Figure 7). In conclusion, these results suggest that $\mathrm{CHOP}$ is a major contributor to Min6 cells apoptosis at hypoxia.

CHOP protein is upregulated in isolated pancreatic islets cultured at normoxia. As our results showed that pancreatic islets cultured at normoxia present intracellular hypoxia (Figures 1a and b) we have investigated whether $\mathrm{CHOP}$ protein was activated in this condition. With this aim we have cultured isolated pancreatic islets for different periods of time and we have assessed protein levels of HIF-1 $\alpha$ and CHOP. Our results show that HIF- $1 \alpha$ accumulated in the islets in culture with the peak of protein stabilization at $8 \mathrm{~h}$ of culture (Figure 8a). Also protein levels of CHOP were upregulated starting as early as $4 \mathrm{~h}$ and remained induced up to $24 \mathrm{~h}$ of culture. These results indicate that although islets are cultured at normoxia, $\beta$-cells became hypoxic with subsequent induction of the pro-apoptotic transcription factor $\mathrm{CHOP}$.

Islets of $\mathbf{d b} / \mathbf{d b}$ mice are hypoxic. Previous studies have shown that islets of the diabetic $\mathrm{db} / \mathrm{db}$ mice have higher levels of apoptotic cells when compared with islets of his counterpart control mice. ${ }^{27,28}$ However, the state of oxygen availability in the islets of these animals has not been previously investigated. We have therefore assessed the potential hypoxic status of these islets by evaluating the formation of pimanidazole adducts. As shown in Figure $8 \mathrm{~b}$ islets of $\mathrm{db} / \mathrm{db}$ mice are stained positively for the hypoxia marker adduct pimonidazole while no staining was detected
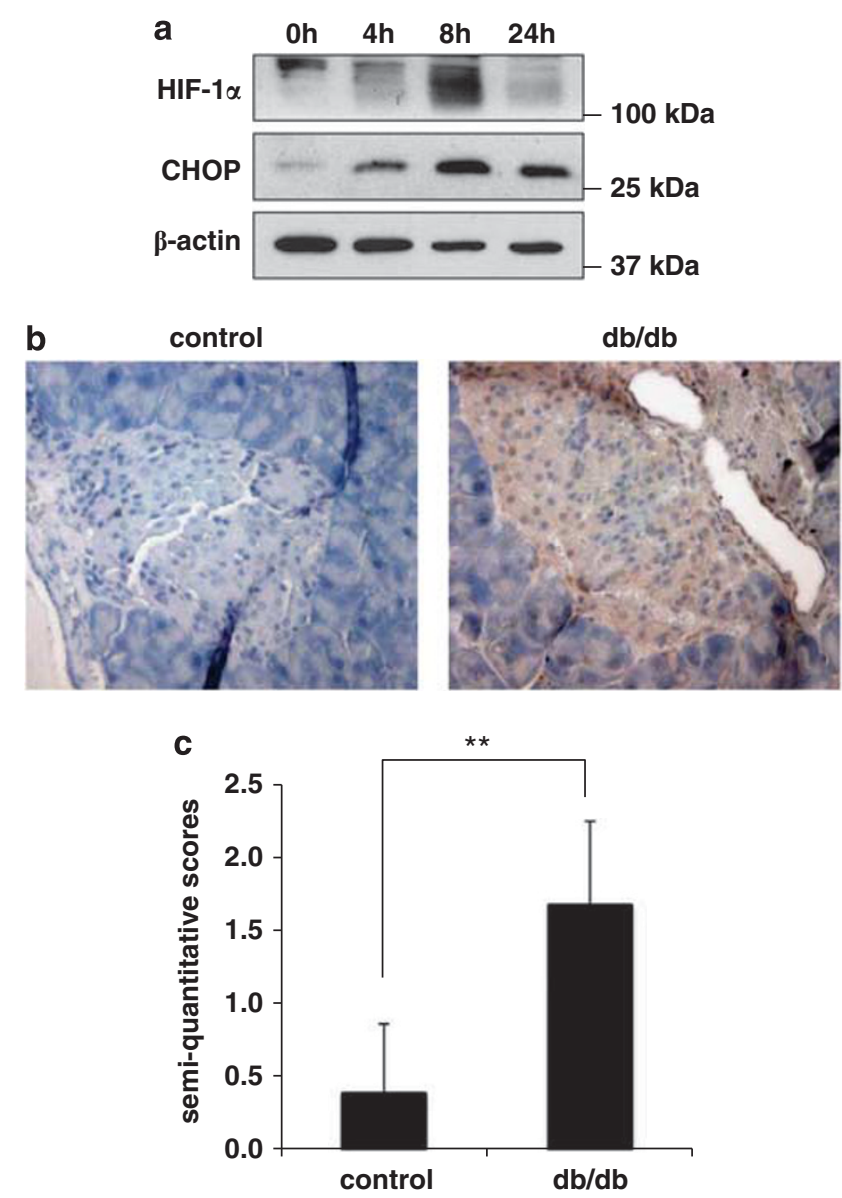

Figure $8 \beta$-Cells in isolated islets in culture and in islets of diabetic $\mathrm{db} / \mathrm{db}$ mouse are hypoxic. (a) CHOP protein is upregulated in isolated pancreatic islets cultured at normoxia. After isolation, islets were cultured for the indicated time points and whole-cell extracts were prepared. HIF- $1 \alpha, \mathrm{CHOP}$ and $\beta$-actin levels were assessed by immunoblotting analysis. (b) Islets of diabetic $\mathrm{db} / \mathrm{db}$ animals are hypoxic. Hypoxia levels evaluated by piminidazole adduct formation in pancreatic islets of normoglycemic control mice (control) or diabetic $\mathrm{db} / \mathrm{db}$ mice $(\mathrm{db} / \mathrm{db}$ ). (c) Semiquantitative evaluation for hypoxiprobe binding within the pancreatic islets $\left(n=3\right.$; values are mean \pm S.D.; ${ }^{\star \star} P<0.05$ relative to control by two-tailed Student's $t$ test)

in the islets of control animals. These observations indicate that $\beta$-cells of $\mathrm{db} / \mathrm{db}$ mice are hypoxic with levels of oxygen below $1.5 \% \quad \mathrm{O}_{2}$ making the above-described apoptotic mechanism a potential pathogenic mechanism in type 2 diabetes.

\section{Discussion}

Pancreatic $\beta$-cells are particularly sensitive to hypoxia, which has been suggested to contribute to the massive cell loss that occurs during the isolation and transplantation of islets. ${ }^{2,29}$ Here we have investigated the mechanism underlying apoptotic $\beta$-cell death in response to hypoxia and we have identified hypoxia of $1 \% \mathrm{O}_{2}$ as a new pathological ER stress inducer in pancreatic $\beta$-cells. Pathological ER stress is induced by exposure of $\beta$-cells to stimuli such as chronic high glucose, free fatty acids and inflammatory cytokines. ${ }^{30}$ The identification of hypoxia of $1 \% \mathrm{O}_{2}$ as a new inducer of 
pathological ER stress highlights the dependence of $\beta$-cell function on molecular oxygen. The correct folding of proinsulin in the ER requires the formation of three disulphide bonds, a process that requires molecular oxygen. ${ }^{31}$ Therefore, lack of molecular oxygen will lead to accumulation of unfolded proinsulin and other proteins compromising $\beta$-cell function and disrupting ER homeostasis.

Molecular oxygen is also consumed in large amounts by $\beta$-cells due to the dependence of insulin secretion on ATP production. Thus, both secretion of insulin and correct folding of proinsulin will be compromised when $\beta$-cells become hypoxic. Interestingly, in contrast to other cell types, $\beta$-cells display a hypoxic phenotype even following very modest reductions in oxygen supply. ${ }^{32}$ The dependence on molecular oxygen for $\beta$-cell function suggests a potential role for hypoxia in type 2 diabetes. Indeed, our results show that islets of $\mathrm{db} / \mathrm{db}$ animals are more hypoxic than their control counterparts. These results are in agreement with a recent study using two other diabetic mouse models, ob/ob and kky, where hypoxia was detected in pancreatic islets. ${ }^{32}$

Hypoxia is known to induce ER stress in cancer cells or MEFs. ${ }^{5-9}$ However, the oxygen levels required for induction of ER stress in these cells are much lower than $1 \% \mathrm{O}_{2}$. In contrast to $\beta$-cells, in cancer cells or MEFs activation of UPR is observed in response to prolonged and severe hypoxia or anoxia $\left(<0.1 \% \mathrm{O}_{2}\right) .{ }^{33}$ In cancer cells or MEFs, severe hypoxia leads to inhibition of global translation and to activation of the transcription factors ATF4 and XBP-1. ${ }^{5-9}$ The involvement of the ATF6 branch of UPR in hypoxiainduced ER-stress has not been as well documented as the two previously described branches. However, ATF6 activation was observed in response to ischemia in a primary cardiac myocyte model. ${ }^{34}$ Activation of UPR has been suggested to protect cells from ER stress-induced apoptosis, as illustrated by the higher sensitivity to hypoxia-induced apoptosis observed in PERK and XBP-1 knockout MEFs. ${ }^{5,7,9}$ However, prolonged or intense hypoxic stress will lead to apoptosis of cancer cells or MEFs. Our results indicate that in Min6 cells the three branches of UPR are activated and all of them contribute to the upregulation of the ER stress-dependent pro-apoptotic regulator $\mathrm{CHOP}$. The key role of $\mathrm{CHOP}$ in the apoptotic process in $\beta$-cells in response to $1 \% \mathrm{O}_{2}$ exposure is clearly demonstrated by the rescue of Min6 cells from hypoxia-induced apoptotic cell death following knockdown of CHOP.

In response to ER stress the translation initiation factor elF2 $\alpha$ is phosphorylated by PERK leading to attenuation of the translation of most mRNAs. ${ }^{10,17}$ Inhibition of translation by the PERK/elF2 $\alpha$ branch of UPR may account for downregulation of gene expression observed at latter time points of hypoxia for several components of the UPR and $\mathrm{Bcl}-2$ family proteins. These observations suggest that in Min6 cells under hypoxia, transcription of hypoxia-target genes is efficiently maintained while the transcription of many non-target genes is inhibited due to repression of translation.

Activation of apoptosis executor caspases is a process that is tightly regulated by the $\mathrm{Bcl}-2$ family proteins. Among these, the $\mathrm{BH} 3-$ only domain proteins PUMA and Bim are known to be activated by ER stress and then convey the signal to the mitochondrial apoptotic machinery. ${ }^{21}$ Early induction of
PUMA and Bim by hypoxia correlates well with the increase in cleaved caspase- 9 and caspase- 3 observed, suggesting that PUMA and Bim are initiators of the apoptotic process in Min6 cells. Changes in expression of BCL-2 family of proteins with the consequent activation of caspase- 9 demonstrate that the intrinsic apoptotic pathway is activated by hypoxia in Min6 cells.

Pancreatic islets transplantation is minimally invasive and therefore has the potential to become a major therapeutic approach to treat type 1 diabetes patients. ${ }^{1}$ However, it is well established that the success of this therapy is jeopardized by the massive cell death occurring during islet isolation and transplantation. ${ }^{1,2}$ This question is highlighted in our study by the cell death occurring in cultured islets kept at normoxia, which was positively correlated with the high levels of intracellular hypoxia. Furthermore, the pro-apoptotic factor CHOP identified in Min6 cells as a major driving factor of hypoxia-induced apoptosis is upregulated in isolated islets after a few hours of culture. Early induction of CHOP protein in cultivated islets indicate an early activation of apoptosis and emphasizes the importance of preventing intracellular hypoxia in order to maintain $\beta$-cell function during islet transplantation.

Previous studies have shown that islets in $\mathrm{db} / \mathrm{db}$ mice have a higher number of $\beta$-cells undergoing apoptosis when compared with islets of control animals. ${ }^{27,28}$ Also UPR components such as Bip and XBP-1 and the pro-apoptotic transcription factor $\mathrm{CHOP}$ have been shown to be upregulated in $\mathrm{db} / \mathrm{db}$ pancreatic islets. ${ }^{35,36}$ Furthermore, an increase in CHOP protein has been observed in human islets of diabetic patients. ${ }^{35}$ The hypoxic state that we have now identified in $\mathrm{db} / \mathrm{db}$ islets and the induction of ER stress and apoptosis that we observed in Min6 cells following exposure to $1 \% \mathrm{O}_{2}$ suggest that hypoxia may trigger $\beta$-cell dysfunction and cell loss during the progression of type 2 diabetes.

In conclusion, we have identified induction of ER stress together with upregulation of the pro-apoptotic $\mathrm{CHOP}$ protein as the main pathway mediating $\beta$-cell apoptosis in response to environmental or intracellular hypoxia. The finding that pancreatic islets of a type 2 diabetic mouse model are hypoxic suggests that hypoxia-mediated $\beta$-cell death may contribute to the progression of type 2 diabetes.

\section{Materials and Methods}

Antibodies and reagents. The antibodies used were as follows: antiCaspase-3 (1:1000, \#9662, Cell Signaling Technology, Danvers, MA, USA), antiCleaved Caspase-3 (1:250, \#9661, Cell Signaling Technology), anti-Caspase-9 (1:500, \#9504, Cell Signaling Technology), anti-Cleaved Caspase-9 (1:250, \#9509, Cell Signaling Technology), anti-LC3B (1:500, ab48394, Abcam, Cambridge, UK), anti-HIF-1 $\alpha$ (1:500, NB100-479, Novus Biologicals, Cambridge, UK), antipimonidazole (1:1000, PAb2627AP, Hydroxyproble, HPI Inc., Burlington, MA, USA), anti-Bad (1:500, 610391, BD Transduction Laboratories, San Jose, CA, USA), anti-p-Bad (Ser112; 1:250, \#5284, Cell Signaling Technology), anti-Bim (1:500, 559685, BD Transduction Laboratories), anti-Bax (1:500, 554106, BD Transduction Laboratories), anti-PUMA (1:200, sc-28226, Santa Cruz Biotechnology, Santa Cruz, CA, USA), anti-Bcl-xL (1:500, 610209, BD Transduction Laboratories), anti-Bcl-2 (1:200, sc-492, Santa Cruz Biotechnology), anti-p-elF2 $\alpha$ (1:200, sc-101670, Santa Cruz Biotechnology), anti-ATF4 (1:200, sc-200, Santa Cruz Biotechnology), anti-IRE1 $\alpha$ (1:500, \#3294, Cell Signaling Technology), anti-pIRE1 $\alpha$ (1:500, NB100-2323, Novus Biologicals), anti-ATF6 (full-length and cleaved forms; 1:200, IMG-273, IMGENEX, San Diego, CA, USA), anti-Bip (1:500, \#3177, Cell Signaling Technology), anti-CHOP (1:200, sc-575, Santa Cruz Biotechnology), 
anti- $\beta$-actin (1:30 000, ab6276, Abcam). Thapsigargin, staurosporine, rapamycin and kanamycin were purchased from Sigma-Aldrich (Steinheim, Germany). Pan-caspase inhibitor Z-VAD-FMK was purchased from Promega (Madison, WI, USA).

Animals and experimental protocol. C57BL/KsJm/Leptdb ( $\mathrm{db} / \mathrm{db}$ ) mice (Stock 000662) and their normoglycemic heterozygous litter-mates were obtained from Charles River (Wilmington, MA, USA), housed five per cage in a 12-h light/dark cycle at $22^{\circ} \mathrm{C}$ and provided ad libitum with standard laboratory food and water. The animals were caged individually for 1 week and handled daily. Isolation of pancreatic islets for cell viability assays was performed from 5-8 week-old female C57BL/6 mice as previously described. ${ }^{37}$ Isolation of pancreatic islets for preparation of whole-cell extracts was performed from 6-month-old male C57BL/6 as previously described. ${ }^{37}$ The animal experimental procedures were approved by the North Stockholm Ethical Committee for Care and Use of Laboratory Animals or the Institutional Committee of Animal Care in the Osaka Medical Center for Cancer and Cardiovascular Diseases.

Staining for pimonidazole adducts. The hypoxia level within the pancreatic islets of mice 12-14 weeks of age was assessed using the Hypoxyprobe kit (Natural-Amersham Pharmacia, Burlington, MA, USA) following the instructions of the manufacturer. Analysis was done blinded by two observers in a semiquantitative manner, using a four-point scale $(0$, no positive cells; 1 , low number of positive cells; 2 , moderate number of positive cells; and 3 , high number of positive cells). Staining for pimonidazole adducts in the isolated islets was described previously. ${ }^{32}$

Cell culture and hypoxia treatment. The mouse pancreatic beta cell line Min6 was kindly provided by Dr. Jun-ichi Miyazaki, Osaka University, Japan. ${ }^{12}$ Min6 cells (passages 20-32) were cultured in Dulbecco's modified Eagles medium (25 mM glucose) containing 10\% heat-inactivated fetal bovine serum, $4 \mathrm{mM}$ L-glutamine, $100 \mathrm{U} / \mathrm{ml}$ penicillin, $100 \mu \mathrm{g} / \mathrm{ml}$ streptomycin and $50 \mu \mathrm{M}$ 2-mercaptoethanol. Primary MBECs (passages 3-10) were cultured in F-12 (HAM) medium supplemented with $10 \%$ fetal bovine serum, $100 \mathrm{U} / \mathrm{mi}$ penicillin and $100 \mu \mathrm{g} / \mathrm{ml}$ streptomycin. Cells were maintained at $37^{\circ} \mathrm{C}$ under $5 \% \mathrm{CO}_{2}, 95 \%$ air conditions. Hypoxic cell cultures were performed in an Invivo2400 hypoxia workstation at $1 \% \mathrm{O}_{2}, 5 \% \mathrm{CO}_{2}, 37^{\circ} \mathrm{C}$.

RNA interference. siRNA Duplexes specific for HIF-1 $\alpha$ (SI00193018), Arnt (SI00904001), ATF4 (SI00905905), XBP-1 (SI01473227), ATF6 (SI00905961) and negative control (1027310) siRNA were obtained from Qiagen (Hilden, Germany). siRNA $(100 \mathrm{nM})$ was transfected into Min6 cells using Lipofectamin 2000 (Invitrogen, Eugene, OR, USA) according to the manufacturer's instructions. Forty-eight hours after transfection, the cells were cultured under normoxic or hypoxic conditions for $24 \mathrm{~h}$ before harvest.

Protein extraction and immunoblotting assays. Cells were lysed in high salt buffer ( $50 \mathrm{mM}$ Tris- $\mathrm{HCl}, 500 \mathrm{mM} \mathrm{NaCl}, 1 \% \mathrm{NP}-40$ and $20 \%$ glycerol) supplemented with $0.5 \mathrm{mM}$ phenylmethylsulfonyl fluoride (PMSF) and $5 \mathrm{mM}$ 2-mercaptoehanol. Isolated islets were sonicated in lysis buffer $(25 \mathrm{mM}$ Hepes, $100 \mathrm{mM} \mathrm{NaCl}, 5 \mathrm{mM}$ EDTA, $20 \mathrm{mM} \beta$-glycerophosphase, 0.5\% Triton X-100, $100 \mu \mathrm{M}$ o-vanadate) supplemented with $20 \mathrm{mM}$ p-nitrophenyl phosphate disodium, $2 \mathrm{mM}$ dithiothreitol, $1 \mathrm{mM}$ PMSF and protease inhibitor mix (Complete-Mini; Roche Biochemicals, Mannheim, Germany). Lysates were cleared by centrifugation for $30 \mathrm{~min}$ at 14.000 r.p.m., and proteins were separated by SDS-PAGE and blotted onto nitrocellulose membranes. Blocking was performed at room temperature for $2 \mathrm{~h}$ in TBS with $5 \%$ nonfat milk, followed by incubation with the different primary antibodies (described above) in TBS with $5 \%$ nonfat milk for either $1 \mathrm{~h}$ at room temperature or overnight at $4{ }^{\circ} \mathrm{C}$. After several washes with TBS containing $0.5 \%$ Tween 20, the membranes were incubated with secondary antibodies of antimouse IgG/HRP (GE Healthcare, Piscataway, NJ, USA) or anti-rabbit IgG/HRP (Cell Signaling Technology) in TBS with 1\% nonfat milk. Following several washes, proteins were visualized using enhanced chemiluminescence (GE Healthcare) according to the manufacturer's instructions.

RNA extraction and quantitative RT-PCR. Total RNA was prepared using the NucleoSpin RNA II (Macherey-Nagel, Düren, Germany) kit, and $1 \mu \mathrm{g}$ of RNA was reversely transcribed using Superscript II Reverse Transcriptase kit (Invitrogen) according to the manufacturer's instructions. Real-time PCR was performed on 7300 Real-Time PCR System (Applied Biosystems) using Power
SYBR Green PCR Master Mix (Applied Biosystems). The PCR primers used were summarized in the table below:

\begin{tabular}{|c|c|c|}
\hline Gene & Forward primer $\left(5^{\prime}-3^{\prime}\right)$ & Reverse primer $\left(5^{\prime}-3^{\prime}\right)$ \\
\hline CASP3 & $\begin{array}{l}\text { GGACTCTGGG } \\
\text { ATCTATCTGG }\end{array}$ & AGATGACATT \\
\hline Bad & $\begin{array}{l}\text { CCTTCAAGG } \\
\text { GACTTCCTC }\end{array}$ & $\begin{array}{l}\text { AAGTTTCGA } \\
\text { TCCCACCAG }\end{array}$ \\
\hline Bim & $\begin{array}{l}\text { GGAGATACGGA } \\
\text { TTGCACAGGAG }\end{array}$ & $\begin{array}{l}\text { CCTTCTCCATA } \\
\text { CCAGACGGAAG }\end{array}$ \\
\hline Bax & $\begin{array}{l}\text { TTGCTACAGG } \\
\text { GTTTCATCCA }\end{array}$ & $\begin{array}{l}\text { CATATTGCTGT } \\
\text { CCAGTTCATCTC }\end{array}$ \\
\hline PUMA & $\begin{array}{l}\text { CGGAGACAA } \\
\text { GAAGAGCAG }\end{array}$ & $\begin{array}{l}\text { GAAGAGATTGT } \\
\text { ACATGACCCT }\end{array}$ \\
\hline$B C l-x L$ & $\begin{array}{l}\text { TACCGGAGAG } \\
\text { CGTTCAGTGA }\end{array}$ & $\begin{array}{l}\text { CCATCCCGAAA } \\
\text { GAGTTCATTCA }\end{array}$ \\
\hline $\mathrm{Bcl}-2$ & $\begin{array}{l}\text { CCTTTCAGCA } \\
\text { TTGCGGAGG }\end{array}$ & $\begin{array}{l}\text { TTACACCGAAC } \\
\text { ACTTGATTCTG }\end{array}$ \\
\hline ATF4 & $\begin{array}{l}\text { CGGCAAGG } \\
\text { AGGATGC }\end{array}$ & $\begin{array}{l}\text { AAGAGCTCA } \\
\text { TCTGGCATG }\end{array}$ \\
\hline$X B P-1$ & $\begin{array}{l}\text { GAAGAAGAGAA } \\
\text { CCACAAACTCC }\end{array}$ & $\begin{array}{l}\text { CCAAGCGTGT } \\
\text { TCTTAACTCC }\end{array}$ \\
\hline ATF6 & $\begin{array}{l}\text { CATTTCGAAG } \\
\text { GGATCATCTG }\end{array}$ & $\begin{array}{l}\text { GTCTTGTGG } \\
\text { TCTTGTTGTG }\end{array}$ \\
\hline$B i P$ & $\begin{array}{l}\text { CATCAATGAG } \\
\text { CCTACAGCAG }\end{array}$ & $\begin{array}{l}\text { GCCACCACT } \\
\text { TCAAAGACAC }\end{array}$ \\
\hline $\mathrm{CHOP}$ & $\begin{array}{l}\text { TGAGTCCCT } \\
\text { GCCTTTCAC }\end{array}$ & $\begin{array}{l}\text { TTGATTCTTCC } \\
\text { TCTTCGTTTCC }\end{array}$ \\
\hline BNIP3 & $\begin{array}{l}\text { ACACCACAAG } \\
\text { ATACCAACAG }\end{array}$ & $\begin{array}{l}\text { GACTTGACCA } \\
\text { ATCCCATATCC }\end{array}$ \\
\hline$H I F-1 \alpha$ & $\begin{array}{l}\text { TGAGAGACTTCT } \\
\text { TCAGGAAAACG }\end{array}$ & $\begin{array}{l}\text { ATCGCTATCCA } \\
\text { CATCAAAGCAA }\end{array}$ \\
\hline Arnt & $\begin{array}{l}\text { TTTATCCCTAGA } \\
\text { GATGGGTACAGG }\end{array}$ & $\begin{array}{l}\text { CCACAGGCTG } \\
\text { GACAGAAACC }\end{array}$ \\
\hline GLUT1 & $\begin{array}{l}\text { TGCTCAGTGT } \\
\text { CATCTTCATC }\end{array}$ & $\begin{array}{l}\text { CTTCTTCAGC } \\
\text { ACACTCTTG }\end{array}$ \\
\hline$P G K 1$ & $\begin{array}{l}\text { AAGTCGAGA } \\
\text { ATGCCTGTG }\end{array}$ & $\begin{array}{l}\text { CTCAGCTTTA } \\
\text { ACCTTGTTTCC }\end{array}$ \\
\hline $18 S$ & $\begin{array}{l}\text { CGGCGACGAC } \\
\text { CCATTCGAAC }\end{array}$ & $\begin{array}{l}\text { GAATCGAACCC } \\
\text { TGATTCCCCGTC }\end{array}$ \\
\hline$\beta$-Actin & $\begin{array}{l}\text { GACAGGATGC } \\
\text { AGAAGGAGAT }\end{array}$ & $\begin{array}{l}\text { TTGCTGATCC } \\
\text { ACATCTGCTG }\end{array}$ \\
\hline
\end{tabular}

Lentiviral transduction for generation of shRNA-mediated stable knockdown cell lines. MISSION lentiviral transduction particles expressing shRNA targeting HIF-1 $\alpha$ (HIF-1 $\alpha \# 1:$ TRCN0000232222, HIF-1 $\alpha \# 2:$ TRCN0000054448) or CHOP (CHOP\#1: TRCN0000103709, CHOP\#2: TRCN0000103707) and lentiviral-negative control particles (SHC002V) were purchased from Sigma-Aldrich. Stably transduced cell lines were generated according to the manufacturer's instructions. Briefly, cells were seeded on a 12-well plate. The following day cells were infected. After $24 \mathrm{~h}$ medium was changed. Selection of stable clones started $24 \mathrm{~h}$ later with the addition of $2 \mu \mathrm{g} / \mathrm{ml}$ of puromycin. Knockdown efficiency of different cell lines was determined by immunoblot analysis and real-time PCR.

TUNEL assay. Apoptotic cells were determined using the DeadEnd Fluorometric TUNEL System (Promega) according to the manufacturer's instructions. Nuclei were counterstained with DAPI and image was captured using a laser scanning confocal microscope (LSM 510, Carl Zeiss, Goettingen, Germany). Apoptosis was also quantitatively determined by flow cytometry of cells stained with a FITC-labeled anti-BrdU antibody using the APO-BRDU kit (BD Pharmingen, San Diego, CA, USA) according to the manufacturer's instructions. Detached cells present in the supernatant were included in the assay.

Viability assay. Cell viability was determined by measuring live-cell protease activity using the CellTiter-Fluor Cell Viability Assay (Promega) according to the manufacturer's instructions. For viability assays in isolated islets, the islets were cultured in RPMI containing $11.1 \mathrm{mmol} / \mathrm{l}$ glucose supplemented with $10 \% \mathrm{FBS}$ for $24 \mathrm{~h}$ under normoxic conditions. Then, the islets were incubated with Calcein-AM 
( $1 \mu \mathrm{g} / \mathrm{ml}$, Invitrogen) and propidium iodide (10 $\mu \mathrm{g} / \mathrm{ml}$, Invitrogen) for $20 \mathrm{~min}$ at $37^{\circ} \mathrm{C}$. After washing the islets with PBS, the images were captured by CDD camera (CoolSNAP, Photometrics, Tucson, AZ, USA) under a microscope (IX70, OLYMPUS, Tokyo, Japan). The ratio of the propidium iodide staining positive islets per total islets was calculated. 46 islets for $0 \mathrm{~h}$, and 52 islets for $24 \mathrm{~h}$ from tree mice each were analyzed.

XBP-1 splicing assay. Total RNA was reversely transcribed using Superscript II Reverse Transcriptase kit (Invitrogen) according to the manufacturer's instructions. The region of XBP-1 containing the splice junction was then amplified by PCR using primers (sense: 5'-AAACAGAGTAGCAGCGCAGACTGC-3'; antisense: $5^{\prime}$-TCCTTCTGGGTAGACCTCTGGGAG-3') with the cycling conditions of $94^{\circ} \mathrm{C}$ for $4 \mathrm{~min}$, followed by 35 cycles of $94^{\circ} \mathrm{C}$ for $10 \mathrm{~s}, 65^{\circ} \mathrm{C}$ for $30 \mathrm{~s}$, and $72{ }^{\circ} \mathrm{C}$ for $30 \mathrm{~s}$. Unspliced (uXBP-1, $476 \mathrm{bp}$ ) and spliced (sXBP-1, $450 \mathrm{bp}$ ) XBP-1 fragments were separated in $3 \%$ agarose gels and visualized by ethidium bromide staining

Caspase-12 activity. Caspase-12 activity was measured by a fluorometric assay kit (BioVision, Mountain View, CA, USA) according to manufacturer's instructions. Briefly, cells were lysed, and proteins $(150 \mu \mathrm{g})$ were transferred into a black-bottom 96-wells microplate and incubated with the caspase-12 substrate ATAD-AFC $(50 \mu \mathrm{m})$ for $1.5 \mathrm{~h}$ at $37^{\circ} \mathrm{C}$. Results were analyzed using a fluorescence plate reader $(E x / E m=400 / 505 \mathrm{nM})$. Control reactions were performed with no protein in the wells and by omitting the substrate.

\section{Conflict of Interest}

The authors declare no conflict of interest

Acknowledgements. We thank Stina Lindberg for technical assistance. We also thank Professor Yihai Cao for the MBECs. This work was support by the Swedish Research Council (to TP, LP and KB), the Swedish Cancer Society (to TP and LP), the European Union FP7, Metoxia (to LP), the Naito Foundation (to MI) and the Family Erling Person Foundation (to KB). XZ is a recipient of a KID fellowship from Karolinska Institutet.

1. Vardanyan M, Parkin E, Gruessner C, Rodriguez Rilo HL. Pancreas vs. islet transplantation: a call on the future. Curr Opin Organ Transplant 2010; 15: 124-130.

2. Carlsson PO. Influence of microenvironment on engraftment of transplanted beta-cells Ups J Med Sci 2011; 116: 1-7.

3. Olsson R, Olerud J, Pettersson U, Carlsson PO. Increased numbers of low-oxygenated pancreatic islets after intraportal islet transplantation. Diabetes 2011; 60: 2350-2353.

4. Lau J, Henriksnas J, Svensson J, Carlsson PO. Oxygenation of islets and its role in transplantation. Curr Opin Organ Transplant 2009; 14: 688-693.

5. Bi M, Naczki C, Koritzinsky M, Fels D, Blais J, Hu N et al. ER stress-regulated translation increases tolerance to extreme hypoxia and promotes tumor growth. EMBO J 2005; 24 3470-3481.

6. Ameri K, Lewis CE, Raida M, Sowter H, Hai T, Harris AL. Anoxic induction of ATF-4 through HIF-1-independent pathways of protein stabilization in human cancer cells. Blood 2004; 103: 1876-1882

7. Koumenis C, Naczki C, Koritzinsky M, Rastani S, Diehl A, Sonenberg N et al. Regulation of protein synthesis by hypoxia via activation of the endoplasmic reticulum kinase PERK and phosphorylation of the translation initiation factor elF2alpha. Mol Cell Biol 2002; 22 7405-7416.

8. Liu L, Wise DR, Diehl JA, Simon MC. Hypoxic reactive oxygen species regulate the integrated stress response and cell survival. J Biol Chem 2008; 283: 31153-31162.

9. Romero-Ramirez L, Cao H, Nelson D, Hammond E, Lee AH, Yoshida H et al. XBP1 is essential for survival under hypoxic conditions and is required for tumor growth. Cance Res 2004; 64: 5943-5947.

10. Volchuk A, Ron D. The endoplasmic reticulum stress response in the pancreatic beta-cell. Diabetes Obes Metab 2010; 12(Suppl 2): 48-57.

11. Eizirik DL, Cnop M. ER stress in pancreatic beta cells: the thin red line between adaptation and failure. Sci Signal 2010; 3: pe7.

12. Miyazaki J, Araki K, Yamato E, Ikegami H, Asano T, Shibasaki Y et al. Establishment of a pancreatic beta cell line that retains glucose-inducible insulin secretion: special reference to expression of glucose transporter isoforms. Endocrinology 1990; 127: 126-132.

13. Moritz W, Meier F, Stroka DM, Giuliani M, Kugelmeier P, Nett PC et al. Apoptosis in hypoxic human pancreatic islets correlates with HIF-1alpha expression. FASEB J 2002; 16: 745-747.

14. Zheng X, Ruas JL, Cao R, Salomons FA, Cao Y, Poellinger $L$ et al. Cell-type-specific regulation of degradation of hypoxia-inducible factor 1 alpha: role of subcellular compartmentalization. Mol Cell Biol 2006; 26: 4628-4641.

15. Greijer AE, van der Wall $E$. The role of hypoxia inducible factor 1 (HIF-1) in hypoxia induced apoptosis. J Clin Pathol 2004; 57: 1009-1014.

16. Cantley J, Grey ST, Maxwell PH, Withers DJ. The hypoxia response pathway and beta-cell function. Diabetes Obes Metab 2010; 12(Suppl 2): 159-167.

17. Fonseca SG, Burcin M, Gromada J, Urano F. Endoplasmic reticulum stress in beta-cells and development of diabetes. Curr Opin Pharmacol 2009; 9: 763-770.

18. Bertolotti A, Zhang Y, Hendershot LM, Harding HP, Ron D. Dynamic interaction of BiP and ER stress transducers in the unfolded-protein response. Nat Cell Biol 2000; 2: 326-332.

19. Luo S, Baumeister P, Yang S, Abcouwer SF, Lee AS. Induction of Grp78/BiP by translational block: activation of the Grp78 promoter by ATF4 through and upstream ATF/ CRE site independent of the endoplasmic reticulum stress elements. J Biol Chem 2003: 278: $37375-37385$

20. Yamamoto K, Yoshida H, Kokame K, Kaufman RJ, Mori K. Differential contributions of ATF6 and XBP1 to the activation of endoplasmic reticulum stress-responsive cis-acting elements ERSE, UPRE and ERSE-II. J Biochem 2004; 136: 343-350.

21. Shore GC, Papa FR, Oakes SA. Signaling cell death from the endoplasmic reticulum stress response. Curr Opin Cell Biol 2011; 23: 143-149.

22. Zinszner $\mathrm{H}$, Kuroda M, Wang X, Batchvarova N, Lightfoot RT, Remotti $\mathrm{H}$ et al. $\mathrm{CHOP}$ is implicated in programmed cell death in response to impaired function of the endoplasmic reticulum. Genes Dev 1998; 12: 982-995.

23. Marciniak SJ, Yun CY, Oyadomari S, Novoa I, Zhang Y, Jungreis R et al. CHOP induces death by promoting protein synthesis and oxidation in the stressed endoplasmic reticulum. Genes Dev 2004; 18: 3066-3077.

24. Puthalakath H, O'Reilly LA, Gunn P, Lee L, Kelly PN, Huntington ND et al. ER stress triggers apoptosis by activating BH3-only protein Bim. Cell 2007; 129: 1337-1349.

25. Harding HP, Novoa I, Zhang Y, Zeng H, Wek R, Schapira M et al. Regulated translation initiation controls stress-induced gene expression in mammalian cells. Mol Cell 2000; 6: 1099-1108.

26. Wu J, Rutkowski DT, Dubois M, Swathirajan J, Saunders T, Wang J et al. ATF6alpha optimizes long-term endoplasmic reticulum function to protect cells from chronic stress. Dev Cell 2007; 13: 351-364

27. Wang X, Liu Y, Yang Z, Zhang Z, Zhou W, Ye Z et al. Glucose metabolism-related protein 1 (GMRP1) regulates pancreatic beta cell proliferation and apoptosis via activation of Akt signalling pathway in rats and mice. Diabetologia 2011; 54: 852-863.

28. Han SJ, Choi SE, Yi SA, Lee SJ, Kim HJ, Kim DJ et al. beta-Cell-protective effect of 2-aminobicyclo-(2,2,1)-heptane-2-carboxylic acid as a glutamate dehydrogenase activator in $\mathrm{db} / \mathrm{db}$ mice. J Endocrinol 2012; 212: 307-315.

29. Miao G, Ostrowski RP, Mace J, Hough J, Hopper A, Peverini R et al. Dynamic production of hypoxia-inducible factor-1alpha in early transplanted islets. Am J Transplant 2006; 6 : 2636-2643.

30. Fonseca SG, Urano F, Burcin M, Gromada J. Stress hypERactivation in the beta-cell. Islets 2010; 2: 1-9.

31. Appenzeller-Herzog C, Ellgaard L. The human PDI family: versatility packed into a single fold. Biochim Biophys Acta 2008; 1783: 535-548.

32. Sato Y, Endo H, Okuyama H, Takeda T, Iwahashi H, Imagawa A et al. Cellular hypoxia of pancreatic beta-cells due to high levels of oxygen consumption for insulin secretion in vitro. J Biol Chem 2011; 286: 12524-12532.

33. Koumenis C, Wouters BG. 'Translating' tumor hypoxia: unfolded protein response (UPR)dependent and UPR-independent pathways. Mol Cancer Res 2006; 4: 423-436.

34. Doroudgar S, Thuerauf DJ, Marcinko MC, Belmont PJ, Glembotski CC. Ischemia activates the ATF6 branch of the endoplasmic reticulum stress response. J Biol Chem 2009; 284: 29735-29745.

35. Laybutt DR, Preston AM, Akerfeldt MC, Kench JG, Busch AK, Biankin AV et al. Endoplasmic reticulum stress contributes to beta cell apoptosis in type 2 diabetes. Diabetologia 2007; 50: 752-763.

36. Kondo T, Sasaki K, Matsuyama R, Morino-Koga S, Adachi H, Suico MA et al. Hyperthermia with mild electrical stimulation protects pancreatic beta-cells from cell stresses and apoptosis. Diabetes 2012; 61: 838-847.

37. Parangi S, Dietrich W, Christofori G, Lander ES, Hanahan D. Tumor suppressor loci on mouse chromosomes 9 and 16 are lost at distinct stages of tumorigenesis in a transgenic model of islet cell carcinoma. Cancer Res 1995; 55: 6071-6076.

(c)

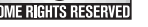
Derivative Works 3.0 Unported License. To view a copy of this license, visit http://creativecommons.org/licenses/by-nc-nd/3.0/ 